\title{
Forestry, pasture, agriculture and fauna correlated to recent changes in Sicily
}

\author{
Massa ${ }^{(1)}$, La Mantia $T^{*(2)}$ \\ (1) Dipartimento SENFIMIZO (Entomologia, Acarologia, Zoologia), Università di Palermo, Viale delle Scienze, 90128 \\ Palermo, Italy; (2) Dipartimento di Colture Arboree, Università di Palermo, Viale delle Scienze, 90128 Palermo, Italy - \\ *Corresponding Author: Tommaso La Mantia (tommasolamantia@unipa.it).
}

\begin{abstract}
Forestry, pasture, agriculture and fauna correlated to recent changes in Sicily. Sicily, due to its position, dimension and variability may be considered representative of the environmental conditions and transformations occurred in the Mediterranean area. In some cases, transformation process was destructive for some habitats, as wetlands; their reclamation caused extinction of some bird species once breeding in Sicily. The transformation, often, changed the proportion among habitats, with a reduction of wood and an increase of cerealicolous-zootechnical areas. The transformation began during the Greek and Roman period but created some open habitats, as prairie or cerealicolous-zootechnical, very rich in biodiversity. Actually in Sicily, the highest number of threatened species are linked to this habitat and are at high risk, due to process of intensification of agriculture, occurring since the II World War. In many areas of Europe species at risk are also presently tied to agrarian systems. Some species living in woodland became extinct because of wood cutting occurred in the past century. Today, due to the protection of woods, their fauna has stable populations or is increasing, because of the re-naturalization process of allochthonous woods. Species present in wetlands are currently increasing thanks to the protection of such habitats. This paper will allow to establish priorities for protection and action that may contribute to the increase of animal biodiversity in Sicily.
\end{abstract}

Keywords: Landscape, Environmental changes, Birds, Mammals, Reptiles, Amphibians, Sicily.

Received: May 31, 2007 - Accepted: Nov 19, 2007

Citation: Massa B, La Mantia T (2007). Forestry, pasture, agriculture and fauna correlated to recent changes in Sicily. Forest@ 4 (4): 418-438. [online] URL: http://www.sisef.it/forest@/.

\section{Introduction}

The current distribution and density of animal species mainly depends on the changes in climatic conditions and on the effects of human activities on habitats (Thomas et al. 2004, Root et al. 2003, Stervander et al. 2005, Rainio et al. 2006). Among the latter the most relevant are agriculture, pasture and forestry, whose relationships with the environment have been repeatedly investigated (see La Mantia 1997). However, we would like to remind and emphasize here that man, once collector and hunter, became, in time, producer. Agriculture, which was a primary productive sector, became the main cause of environmental changes.

Some changes were often drastic and devastating, largely affecting expansion and/or decline processes of animal species. Such process concerned species living in habitats that were constantly reduced, as wetlands, steppic areas and woodlands, never replaced by similar newly established biotopes.

Nevertheless, in the '800s the influence of agrosilvopastoral activities in Sicily did not cause disastrous events in wildlife, since energy sources and products for agriculture remained natural or ecocompatible. Problems began when farmers, during their legitimate freeing process from agricultural traditional forms of work, massively applied mechanization, aiming at increasing productivity (La Mantia \& Barbera 2003) and introduced foreign molecules into biogeochemical cycles. Since then it has been necessary to make a great effort, which has also taken quite a long time, to aim at re-establishing agrosilvopastoral forms, more compatible with the environment. 
However, as far as fauna's decline is concerned, there is some uncertainty in assigning great and direct responsibility to agricultural activities; probably a very bad and unadvised territorial management was the real reason of the extinction and the decline of some animal populations. Mediterranean vegetation is considered resilient, maquis very easily reverts to woodland if woodcutting, browsing and burning stop (Grove \& Rackham 2001). Environmental changes affected by agrosylvopastoral activities likely produced population fluctuations of animal species, which, in turn, showed a high resilience and ability to adapt to new habitats; however, specialized species were unable to adapt themselves to newly established habitats (e.g., Little Bustard Tetrax tetrax, Andalusian Hemipode Turnix sylvatica, etc.).

In this paper we are going to describe recent changes in forestry, agriculture and pasture which have involved changes in the Sicilian fauna distribution, causing its decline, as well as its increase.

\section{Materials and Methods}

\section{Study area}

The Mediterranean Basin is one of the most important plant biodiversity hot-spots of the world (Médail \& Quézel 1997, Heywood 1998, Myers et al. 2000). Due to its peculiar position, Sicily (about $25000 \mathrm{Km}^{2}$ ) played and still plays a major role for plant dispersal, survival, and evolution within this region. 2.793 native vascular plants live on the island (Conti et al. 2005); many are endemic, rare, depleted and/or threatened taxa. The reason of the high biodiversity depends on the biogeographic history, which in turn influenced the high variability of environmental conditions. Plains cover $14.2 \%$ of the territory, hills $61.4 \%$ and mountains $24.4 \%$. There are high lithological differences present on Sicilian soil associations, showed by 33 different types (Fierotti 1988). According to Rivas-Martinez classifications, main bioclimatic zones are infra, thermo, meso, supra, oro and crioro Mediterranean (Brullo et al. 1996). According to Corine Land Cover level 1, agricultural areas cover 1785583 ha, forest and semi-natural areas 674511 ha, wetlands 2791 and artificial surfaces 112937 ha.

\section{Source of data and methodologies}

Changes in the soil use were drawn from La Mantia \& Barbera (2003); data on the application of Rural Development Policy carried out by the Sicilian Region were extracted and processed from rules ap- plied by the Assessorato Regionale Agricoltura e Foreste Regione Siciliana. Old changes of the Sicilian landscape are based on the historical literature, cited along the text.

Data on the presence and possible decline of mammals, reptiles and amphibians were drawn from literature and personal information acquired in Sicily, during the last twenty years. Distribution and population trend of bird species derive from data acquired during the achievement of the Sicilian Atlas Projects (1979-1983: Massa 1985; 1984-1992: Lo Valvo et al. 1993; 1993-2006: AAVV 2007). Overall population trends of bird species (1984-1992 and 1993-2006 periods) was estimated as follows: $0=$ stable; $-1=$ moderately declining (less than $50 \%$ ); $-2=$ largely declining (more than 50\%); $+1=$ moderately increasing (less than $50 \%$ ) $;+2=$ largely increasing (more than $50 \%)$.

According to BirdLife International (2004), among the 524 European species, 226 are classified as Spec13 , needing special conservation measures; European Spec1 $(n=40)$ are species of global conservation concern, Spec2 $(n=45)$ have unfavourable conservation status and are mainly concentrated in Europe, Spec3 ( $n=141$ ) have unfavourable conservation status, but are not mainly concentrated in Europe; furthermore the NonSpec ${ }^{\mathrm{E}}(\mathrm{n}=94)$ have favourable conservation status, but are mainly concentrated in Europe. We gave a "weight" to bird species recorded as Spec1-3 and NonSpec ${ }^{\mathrm{E}}$, to those listed in the Italian Red List of breeding birds (RL) by LIPU-WWF (1998) and to those reported in the Appendix I of the 79/409 Bird Directive; intrinsic value of birds was estimated as follows: $\Sigma$ (Spec) $+(\mathrm{RL})+(79 / 409)$, being Spec1 $=1$, Spec2 $=0.75$, Spec3 $=0.50$, NonSpec $^{\mathrm{E}}=0.25$; EX (extinct species $)=1, C R$ (critically endangered $)=0.80$, $\mathrm{EN}$ (endangered) $=0.60, \mathrm{VU}$ (vulnerable) $=0.40, \mathrm{LR}$ $($ at lower risk $)=0.20 ; 79 / 409=1($ cf. Tab. 6).

\section{Results and Discussion}

\section{Changes in forestry and agriculture}

\section{Rural Development Policy (RDP) in Sicily}

Agriculture generally declined and is no longer a major part of the economics of south European countries (Grove \& Rackham 2001). Baldock et al. (1993) pointed out that agriculture has undergone changes of two types: 1) farm practices (growth or decrease of livestock densities, stable raising, changes in the turnover cultivation, tillage dates, harvest and inputs); 2) changes imposed by the land use (conver- 
sion towards a radically different kind of agriculture, as the irrigated system, total abandonment of agriculture or passage to forestry). Both cases produce a gradual loss of system's natural equilibrium. Conversely, agriculture may beneficially affect land use through traditional land management practices, as low density pasture in economically secondary areas, mainly dependent on natural or seminatural pastures, or on not irrigated cereal extensive cultivation (like in wide areas of southern Europe), these last being considered practices of high natural value (Dixon 1994). In recent years, the subsidized production of hard wheat (for production of pasta) allowed to cultivate unstable land, which should have been otherwise abandoned with a consequent acceleration towards an erosion process.

The high involvement of farmers to the set-aside measure is strictly linked with the crisis of wheat production. During the application of set-aside measure (1989-94), about $25 \%$ of the entire Italian territory destined to this practice was located in Sicily. This measure has been partially replaced by the F2 measure of the EEC Reg. 2078 during 1995-98 period, interested 1344 farms for a surface of 10073 ha (La Mantia \& Barbera 2003). In 2001 the Sicilian region adopted and applied the Rural Development Policy (RDP) 2000-2006 foreseen by the European Union. It should be pointed out that RDP promotes specific eco-compatible actions: reduction of inputs; sowable ground transformation into grazing; integrated and biological agriculture; twenty year retirement from the production; re-establishment and maintenance of traditional agrarian landscape; increase of natural and seminatural areas; management models potentially favouring animal populations.

Overall percentage of the agrarian surface where RDP was applied (97366.05 ha) on the total amount of Usable Agrarian Surface (UAS - 1281654.84 ha) varied very much in the nine provinces of Sicily, with the lowest values in the Agrigento and Caltanissetta $(6-7 \%)$ and the highest in the Ragusa and Siracusa provinces (16.3\% and $21.2 \%)$. Altogether, regional commitment interested $11.47 \%$ of the UAS. Agri-environment regulations aimed also at improving marketing conditions and preserving farmer's health. An important application of this objective, biological agriculture ranged from 1.3\% (Agrigento) to 13.0 and 13.1 (Enna and Ragusa respectively). Regional commitment in this case involved $7 \%$ of UAS. 15341.39 ha (15.8\% of RDPs) was applied within protected areas (Natural Parks, Nature Reserves, etc.); the most important areas in this case lie within
Parks, which show different agriculture traditions. Nebrodi Park has developed pastures and sowable grounds in order to feed livestock and extensive cattle breeding activities, agriculture in the Madonie Park is more characterized by sowable grounds, while Etna Park holds many hazel groves, pistachio groves and vineyards.

We also highlight that some traditional forms of agriculture maintain a rich habitat mosaic, which allows the growth of arthropod diversity in the agroecosystems (Ryszkowski et al. 1993). Mediterranean grasslands usually hold annual plant species, which arise after autumn rains and produce seeds in spring, then die, at the beginning of the summer, remaining as seeds on the ground. Overgrazing encourages a limited number of herbaceous resistant species (like some thistles), reducing floristic quality and diversity (Beaufoy et al. 1994); conversely, a moderate livestock pressure promotes nutritional diversity and quality of grazing, favouring the presence of legume species, which enrich the soil with nitrogen.

\section{Changes in the forestry}

In 1847, for over thirty years, half of the Sicilian wood surface was cut, especially to provide fuel for sulphur mines (Mack Smith 1968). According to a survey of 1911, 98.000 ha of wood still covered the island, but, after the II World War, only 85643 ha remained, therefore counting for $3.3 \%$ of Sicily's surface. Deforestation and land reclamation produced an important hydrogeological and environmental instability. Water sources and river flows were drastically reduced; erosion interested at least $40 \%$ of land. After half of the past century the wood surface increased from 86000 (1947) to 159000 ha (1966 - La Mantia \& Barbera 2003). From half of the $70 \mathrm{~s}^{\prime}$ to 2003, wood surface increased only from 200000 to 222000 ha, due to wildfires, which burned 6000 ha/year in twenty years, with peaks of 16000 in 1988. Fires concerned mainly maquis and conifer wood, much less natural forests. Generally, afforestations were carried out using exotic species; indeed, 130000 ha are "artificial woods", as Eucalyptus (35000) and Pinus sp. (92.000: 43\% P. halepensis, 39\% P. pinea, 17\% $P$. nigra). From an environmental point of view, afforestations did not increase biodiversity for two reasons: 1) effects of afforestation techniques reduced pre-existing biodiversity (Pasta \& La Mantia 2001a, La Mantia \& Pasta 2001); 2) current wooded areas consist of many exotic species, as Eucalyptus, or conifers (Pinus, Cedrus, Cupressus), often subjected to fires, almost completely lacking of naturalistic in- 
terest (La Mantia 2002) in particular for flora biodiversity (Pasta \& La Mantia 2001a, La Mantia \& Pasta 2001, unpublished data) and fauna (Massa et al. 2004).

As far as point 1) is concerned, it must be considered that until the $60 \mathrm{~s}^{\prime}$ implanting work was done manually. Due to the fact that mostly steep grounds had to be forested, the solution was terracing, which would have permitted to safeguard the existing shrub vegetation. Instead, the adoption of mechanization caused serious land losses and a significantly reduced diversity (Pasta \& La Mantia 2001a, La Mantia \& Pasta 2001).

The main problem of wood management is fire prevention; in most cases in fact, the slow and gradual re-naturalization process, occurring in conifer afforestations is interrupted by fire. During the last century, the silviculture has also undergone some changes, and even if there were some rare cases of forest management, these changes were mainly limited to wood cleaning, fire prevention and unavoidable progressive anthropization. In many cases management of protected areas proceeded to a dogmatic conversion from coppices to high forest, without any planning. Public and private bodies managing woods in Sicily addressed forest management mainly to hydrogeological and/or naturalistic functions, and rarely to their silvicultural utilization.

Furthemore wood plantations, between forest activity and agriculture (about $35000 \mathrm{ha}$ ), took place in Sicily under the EEC regulation 2080/1992, but a greater part of those surfaces has been wrongly misused due to incorrect technical choices (La Mantia et al. 2000) with serious repercussions on the landscape and the biodiversity (La Mantia 2002, La Mantia \& Pasta 2005).

\section{Changes in agriculture and cattle breeding}

While it is difficult to provide quantitative data on the evolution of Sicilian agriculture landscape, it is possible to highlight the qualitative process causing this change. Likely, a first heavily modifying phase took place during Greek and Roman dominations. During that period in fact, the first important habitat changes, mainly characterized by massive deforestation, occurred. From the V to the VII century, due to a long period of population decrease and of agricultural decline, fertile land and cultivated fields were abandoned, while sheep-rearing prevailed. After the fall of the Roman Empire and the barbarian invasions, the Arabs settled in, dominating, and agriculture increased. Deserted latifundia were cultivated and new plantations (the so-called mediterranean garden) gave Sicily a new landscape shape. Consequently, forests, marshes and uncultivated land increased. Between the XI and the XIII century further changes, land reclamations and tillages occurred and above all, forests suffered from man's interference. In the following centuries, anthropic pressure in the country diminished, mainly far from the coasts, and in the XV century, thanks to the sugar cane diffusion, coastal woods of a great part of western and eastern Sicily were definitely destroyed. Overall, the last serious period of destruction and environmental changes occurred when Italy became a unified country. Splitting of the estates, poverty and the need of land to cultivate produced a further wide deforestation; the maximum cutting of woods took place during the second half of the 1800s and the beginning of the 1900s, when sulphur mines exploitation and agricultural contingencies produced a further important wood cutting with a contemporary tillage and ploughing of wide inland areas carried out by a rural population still living in a semi-feudal condition. Since then, vineyards, citrus and olive plantations were spreading along coastal plains, rivers and hills, maintaining the same characteristics that are still found nowadays. Nevertheless, during the last fifty years, a more modern agriculture replaced the traditional one, and the use of mechanization and pesticides allowed to increase farm crop productivity. Finally, the unadvised development of industry, tourism, and population caused a degradation previously not recorded.

As far as climate in the Mediterranean area is concerned, there is no evidence, since 1850, of a general wet or dry trend. Grove \& Rackham (2001) report that the 1850s tended to be wet and the late 1860s dry, then a generally wet period from 1880 to 1900 followed, from then until 1925 no clear pattern emerged, the late 1920s and early 1930s were dry, the late 1930s wet, the mid 1940s dry, the 1960s were generally wet, the early 1970s, 1980s and early 1990s dry, the late 1990s wet. Rainfall data show a decline from 1950 to 1990.

Extensive agriculture, still widespread in southEuropean countries and generally along countries bordering the Mediterranean, is characterized by low inputs, low productivity, absence of irrigation systems, low numbers of livestock, regular fallow practice and high vegetation heterogeneity. The introduction of innovative agriculture techniques after 1960 (Tab. 1) disfigured deeply the agrarian landscape, mainly the cerealicolous-zootechnical one, produ- 
Tab. 1 - Changes occurred in the sicilian agroecosystems before and after 1960 (greenhouses, horticulture and industrial culture are excluded).

\begin{tabular}{|c|c|c|}
\hline Agroecosystems & Traditional systems before $1950-1960$ & Modern systems after 1960 \\
\hline \multirow[t]{5}{*}{ Cerealicolous } & Crop rotation with legumes & Monoculture \\
\hline & $\begin{array}{l}\text { Manuring and scarce supplement with } \\
\text { chemical fertilizer }\end{array}$ & Chemical fertilization \\
\hline & $\begin{array}{l}\text { Manual tillage or assisted by farm anim- } \\
\text { als }\end{array}$ & Mechanical tillage, chemical weedkiller \\
\hline & Old varieties & New varieties \\
\hline & Traditional system of seeding & Seed tanning \\
\hline \multirow{6}{*}{$\begin{array}{l}\text { Citrus, Olive planta- } \\
\text { tions, Vineyards, etc. }\end{array}$} & Manuring & Chemical fertilization \\
\hline & $\begin{array}{l}\text { Manual tillage or assisted by farm anim- } \\
\text { als }\end{array}$ & Mechanical tillage, chemical weedkiller \\
\hline & Pruning & $\begin{array}{l}\text { Changes of tree growing shape and new } \\
\text { pruning techniques }\end{array}$ \\
\hline & Low control of disease with pesticides & Control of adversities with pesticides \\
\hline & Old and authochtonous cultivars & New varieties and species \\
\hline & Traditional system of irrigation & Introduction of new irrigation systems \\
\hline \multirow{3}{*}{$\begin{array}{l}\text { Almond, Hazel, } \\
\text { Carob groves (orch- } \\
\text { ard to be neglected) }\end{array}$} & Manuring, green manure & Scarce use of chemical fertilizers \\
\hline & $\begin{array}{l}\text { Manual tillage or assisted by farm anim- } \\
\text { als }\end{array}$ & Mechanical tillage \\
\hline & Pruning & Pruning \\
\hline \multirow[t]{5}{*}{ Table wine } & - & Chemical fertilizers \\
\hline & & Mechanical tillage \\
\hline & & $\begin{array}{l}\text { Massive control of adversities with pesti- } \\
\text { cides and weed killers }\end{array}$ \\
\hline & & Mulching \\
\hline & & New varieties \\
\hline \multirow[t]{2}{*}{ Pastoral } & Transumance & Food integration \\
\hline & Old races & New races \\
\hline
\end{tabular}

cing a great decline of animal populations, in particular of some bird species linked to traditional agroecosystems.

Beyond the agronomic techniques, after the postwar period spreading of cultivations changed (La Mantia \& Barbera 2003). Tree plantations are characterized by the disappearance of traditional orchards; they involve, particularly, almond trees (from 266800 ha - pure and mixed orchards - on 1961 to 75940 ha pure orchards - on 1991 to 65235 ha - pure orchards - on 2000) characterizing inland and coastal hill landscapes. This species is traditionally cultivated on hilly land and contributes to the reduction of soil erosion, which becomes more and more widespread on the entire Sicilian territory. Carob tree, a typical element of the Iblean landscape, is also largely decreasing (from 70800 ha - pure and mixed orchards on 1961 to 27720 - pure orchards - on 1991 to 26545 pure orchard - on 2000). Other tree cultivations, such as chestnut (characterizing mountain landscape) 
have almost nearly disappeared because of disease problems, as well as economical reasons (La Mantia et al. 1999).

In other cases, as that of the citrus groves, the stability of the cultivated area is evidenced, while other cultivations, as grapevines, are undergoing towards an extensive decline. The decrease of grapevine areas (from 221750 ha - pure and mixed orchards - on 1961 to 159800 ha - pure orchards - on 1991 to 143800 ha pure orchards - on 2000) is caused by a more generalized problem at EU level. Traditional "small trees" system of cultivation has a low impact but is also unproductive; intensification (modern cultivation shape) on the other hand, leads to the loss of the typical traditional landscape of the coastal hills. As far as grape are concerned, the increase of cultivated areas (from 16600 ha - pure and mixed orchards - on 1961 to 26610 ha - pure orchards - on 1991, but decreasing to 17996 ha - pure orchards - on 2000) expanded mainly due to intensive cultivation of the "Italia" variety. Cultivation techniques of "Italia" grapes, using plastic coverings, determines a worsening of the microclimatic conditions and forces farmers to a frequent use of pesticides, therefore causing serious problems of residual toxic contents, especially in the late production. Moreover, increased irrigation needs give birth to strong impoverishment and salinisation of the water stratum.

More radical changes concern open field cultivations. In the Sicilian inland areas, characterized by a good integration between agriculture and cattle breeding, traditional cultivations, like cereals and legumes, have been strongly changed. In the first decades of the last century, some cultivated species and varieties which characterized these agricultural systems disappeared. Wheat old varieties were able to produce high amounts of straw for animals as food or bedstraw, as well as to fight against weeds; even if their productivity was stable, they were poorly productive. New varieties are more productive, shorter, and especially require high inputs of fertilizers (La Mantia \& Barbera 2003, Pasta \& La Mantia 2001b). The general decrease of the surfaces used for dry cultivations (wheat from 649900 ha on 1961 to 381700 ha on 1991 to 334100 ha on 2000) overlaps with the legume decline and mainly with the reduction of Italian Sainfoin (Hedysarum coronarium - from 188400 ha on 1961 to 125600 on 1991 to 90940 ha on 2000).

Areas cultivated with legumes (Vicia faba, Lens esculenta and Cicer sativum) decreased from 249470 ha in 1961 to 62170 ha on 1991, and to 28795 ha in 2000.
Today, an increasing interest for balanced diets, with a progressive reduction of animal proteins and an increase of vegetable in human feeding, renewed interest towards these cultivations. Because of land abandonment, a recent increase of pasture areas produced an increase of sheep, and not of cattle. The latter indeed are preferably reared in modern structures; therefore bovines increased from 330000 in 1961 to 528000 in 2000, ovines from 591000 to 1291000, caprines decreased from 218000 to 205000, pigs from 103000 to 98000 and equines from 266000 to 99000 (La Mantia \& Barbera 2003). Furthermore, during the last century, ovines strongly declined and this was possibly the main reason why vultures decreased and disappeared. At the beginning of the last century Coppola (1922) already reported that "of the magnificent herds of thousands of cattles that used to be the honour and pride of the Sicilian manor farms, it does not remain more than a few rare examples". Just before the II World War ovines were around a million, equines and caprines about 400000, bovines and pigs 200000 (Morici 1940).

Large herds were closely linked to turnover systems and their changes caused the disappearance or decline of some bird species of cerealicolous areas. Formerly, different turnover systems were applied, namely three years with wheat-pasture-fallow fields or five years with fallow-wheat-pasture-pasture, thus providing to birds large possibilities to find undisturbed nesting sites and adjacent feeding areas too (Coppola 1922). Other turnovers, like the pasture-pasture-wheat or the fallow field (or broad bean)-wheat-pasture, allowed the presence of large herds.

The areas of industrial cultivations (tobacco, fiber and seeds species) decreased from 21300 ha in 1961 to 300 in 2000, but floriculture and greenhouse products increased, reaching in the last years international markets (from 300 ha in 1961 to 10400 in 2000). Concerning the last ones, from 1981 onwards they have remarkably influenced the economical development of the entire territory of Ragusa. In this case, like for "Italia" grapes, spreading of greenhouse systems had a remarkable socio-economic influence on the territory, but in the last years it has undergone a deep economic crisis. Greenhouses also produced highly negative effects on the environment and on the health of people working there.

Finally, cereal-zootechnical landscape and that of coastal plains were subjected to the highest transformations as a result of the introduction of irrigation methods and afforestation actions. These con- 
versions produced an intensification of agriculture; from the 1940s to the 1980s, farmers were economically encouraged towards this intensification, thus producing soil erosion. Additionally, mechanization increased remarkably, the horse-power (in thousands) increased from 223 in 1961 to 6183 in 1991 and the mechanical power hectares ${ }^{-1}$ also increased from 0.88 in 1971 to 4.3 in 1999. Among all pesticides the use of herbicides increased from $9100 \mathrm{~kg}$ in 1961 to 1613700 in 1999 while the use of fumigants increased from 165300 to $3875600 \mathrm{~kg}$.

\section{Faunal change}

\section{Large Mammals and Birds become extinct}

Due to scarce references, we are not able to understand exactly how the changes above described affected the distribution, increase or decline of small mammals, reptiles and amphibians. Conversely, references and precise information on large mammals and birds decline give us the possibility to show their trend between the half of the 1800s and that one of the 1900s (La Mantia \& Cannella, in press).

Tab. 2 lists seven large mammals which have become extinct in Sicily, also recording some possible causes of their decreasing and extinction. Most of them were seriously affected by habitat loss and hunting between 1800 and 1850. For what concerns the Otter (Lutra lutra), it seems possible that the species had already become extinct in the first half of 1800s, and not in 1954 (when drainage of the Lentini lake was completed), as supposed by Sarà (1999).
Only two of these seven species still lived in the 1900s, the Monkseal (Monachus monachus) and the Wolf (Canis lupus), whose extinction was mainly due to human persecution, respectively by fishermen and shepherds.

Changes and reconversions that have taken place over hundreds of years, producing a complex agrosilvopastoral landscape, characterized by seral stages, ecotones and secondary successions, favoured many species of birds of shrubby, steppic and open habitats. In the last century, further changes, mainly due to land exploitation, caused the extinction of some of them. Tab. 3 lists 14 bird species extinct in Sicily before and after 1960 . We assume that only four of them were actually effected by agriculture and cattle breeding changes, namely Francolin (Francolinus francolinus), Andalusian Hemipode (Turnix sylvatica), Griffon Vulture (Gyps fulvus) and Little Bustard (Tetrax tetrax). Drainage of wetlands caused the decline of another four species, while supposedly the Lammergeier (Gypaetus barbatus), the Osprey (Pandion haliaetus), three species of woodpeckers (Dryocopus martius, Picus viridis and Dendrocopus minor) and the Eagle Owl (Bubo bubo) were decreasing for a genetic bottleneck phenomenon, being at the southern edge of their distribution. Nevertheless, woodland was reduced to $10 \%$ at the beginning of the I World War and to $3.3 \%$ after the II World War, and eventually produced the decline (or extinction) of some stenoecious forest species (e.g., woodpeckers).

Tab. 2 - Large mammals become extinct in Sicily. Some Mammals (Capreolus capreolus for example) are considered allochthonous species in Sicily, introduced by man.

\begin{tabular}{|c|c|c|c|}
\hline Species & $\begin{array}{l}\text { Extinction } \\
\text { year }\end{array}$ & Causes & References \\
\hline Monachus monachus & after 1975 & $\begin{array}{l}\text { Human persecution; genetic } \\
\text { drift? }\end{array}$ & La Mantia \& Massa 1972 (in press) \\
\hline Canis lupus & about 1935 & Hunting, human persecution & La Mantia \& Cannella (in press) \\
\hline Lutra lutra & before 1850 ? & $\begin{array}{l}\text { Habitat loss, human interference } \\
\text { genetic drift? }\end{array}$ & La Mantia \& Cannella (in press) \\
\hline Capreolus capreolus & about 1870 & $\begin{array}{l}\text { Hunting, human interference, } \\
\text { habitat loss }\end{array}$ & La Mantia \& Cannella (in press) \\
\hline Cervus elaphus & before 1800 & $\begin{array}{l}\text { Hunting, human interference, } \\
\text { habitat loss }\end{array}$ & La Mantia \& Cannella (in press) \\
\hline Dama dama & 1845 & $\begin{array}{l}\text { Hunting, human interference, } \\
\text { habitat loss }\end{array}$ & La Mantia \& Cannella (in press) \\
\hline Sus scrofa & about 1870 & Hunting, human interference & La Mantia \& Cannella (in press) \\
\hline
\end{tabular}

C Forest@ 4 (4): 418-438, 2007. 
Tab. 3 - Bird species become extinct in Sicily.

\begin{tabular}{|c|c|c|c|}
\hline $\begin{array}{l}\text { Species } \\
\text { before } 1960\end{array}$ & Extinction year & Causes & References \\
\hline Netta rufina & after 1943 & Drainage of wetlands & Stresemann 1943 \\
\hline $\begin{array}{l}\text { Oxyura } \\
\text { leucocephala }\end{array}$ & before 1869 & Drainage of wetlands & Zuccarello Patti 1845 \\
\hline Gypaetus barbatus & after 1916 & $\begin{array}{l}\text { Very small population, genetic } \\
\text { drift }\end{array}$ & Minà-Palumbo 1857 \\
\hline $\begin{array}{l}\text { Francolinus } \\
\text { francolinus }\end{array}$ & about 1840 & $\begin{array}{l}\text { Hunting, habitat transformation, } \\
\text { etc. }\end{array}$ & Lilford 1862, Doderlein 1874 \\
\hline $\begin{array}{l}\text { Porphyrio } \\
\text { porphyrio }\end{array}$ & after 1950 & Drainage of wetlands, hunting & Iapichino \& Massa 1989 \\
\hline Turnix sylvatica & about 1920 & $\begin{array}{l}\text { Hunting, habitat transformation, } \\
\text { land reclamation }\end{array}$ & $\begin{array}{l}\text { Orlando 1958a, Violani \& } \\
\text { Massa } 1993\end{array}$ \\
\hline Dryocopus martius & $\begin{array}{l}\text { before 1900; probably } \\
\text { wandering from Italy, } \\
\text { not breeding in Sicily }\end{array}$ & Genetic drift? Wood cutting? & $\begin{array}{l}\text { Doderlein 1874, Trischitta } \\
\text { 1919, Orlando } 1956\end{array}$ \\
\hline Picus viridis & about 1930 & Genetic drift? Wood cutting? & $\begin{array}{l}\text { Orlando 1956, Iapichino \& } \\
\text { Massa } 1989\end{array}$ \\
\hline $\begin{array}{l}\text { Dendrocopus } \\
\text { minor }\end{array}$ & about 1930 & Genetic drift? Wood cutting? & Orlando 1956 \\
\hline Panurus biarmicus & between 1930 and 1950 & Drainage of wetlands & Orlando 1958b, Priolo 1954 \\
\hline \multicolumn{4}{|c|}{ after 1960} \\
\hline Pandion haliaetus & about 1968 & $\begin{array}{l}\text { Human interference to breeding } \\
\text { sites. Genetic drift? }\end{array}$ & Massa 1973 \\
\hline Gyps fulvus & 1965 & $\begin{array}{l}\text { Hunting, habitat transformation, } \\
\text { changes of pastoral and agriculture } \\
\text { activities }\end{array}$ & Priolo 1967 \\
\hline Tetrax tetrax & about 1970 & Hunting, agriculture changes & Iapichino \& Massa 1989 \\
\hline Bubo bubo & $\begin{array}{l}\text { last confirmed breed- } \\
\text { ing: 1935; last observa- } \\
\text { tion: } 1978\end{array}$ & $\begin{array}{l}\text { Genetic drift? Hunting? } \\
\text { Wood cutting? }\end{array}$ & Sarà et al. 1987 \\
\hline
\end{tabular}

\section{Current status of terrestrial Reptiles, Amphibians} and Mammals in Sicily

Only five species of Amphibians live in Sicily (Tab. 4); another two (Salamandra salamandra and Triturus carnifex) have been repeatedly recorded (e.g., Lo Valvo 1998, Turrisi \& Vaccaro 2001), but their past and current presence should be confirmed (AA VV 2007). Two species (Discoglossus pictus and Hyla intermedia) declined in the last years, because of pollution, habitat loss and alteration and conversion from old irrigation systems to modern ones (La Mantia 2004). Some 21 species of Reptiles are currently present in Sicily, six of which live only on surrounding islands; only one (Testudo hermanni) has to be considered critically endangered, others are only slightly affected by negative factors.

On the whole, 23 terrestrial Mammals currently live in Sicily, four of which have been recently introduced (Tab. 5); in 1980 the Azienda Foreste Demaniali of Sicilian Region carried out the re-introduction of the Fallow Deer (Dama dama) and the Wild Boar (Sus scrofa), regrettably without preceding it by a feasibility project, and presently the Wild Boar produces some damages to horticulture and possibly to wood clearings (La Mantia et al. 2004). Due to rare datasets available, we did not list Chiroptera species; most of them are considered as critically endangered by pesticide use and direct man persecution (Fornasari et al. 1997). Among autochthonous species today, the most endangered in Sicily is probably Felis sil- 
Tab. 4 - Reptiles and Amphibians living in Sicily and their status (sources: La Mantia 1997, Lo Valvo 1998, Turrisi \& Vaccaro 2001, Corti \& Lo Cascio 1999, pers. observ.). ${ }^{*}=$ endemic taxa.

\begin{tabular}{|c|c|c|c|}
\hline Species & Status & Habitat & $\begin{array}{l}\text { Factors affecting eventual } \\
\text { decline }\end{array}$ \\
\hline \multicolumn{4}{|l|}{ Amphibia } \\
\hline Discoglossus pictus & $\begin{array}{l}\text { Uncommon and decreasing } \\
\text { in the orchards }\end{array}$ & $\begin{array}{l}\text { Small rivers, ponds and water basins, } \\
\text { often in agroecosystems }\end{array}$ & $\begin{array}{l}\text { Removal and conversion from old irriga- } \\
\text { tion systems to modern ones }\end{array}$ \\
\hline Bufo bufo & $\begin{array}{l}\text { Common and widespread, de- } \\
\text { creasing in the orchards }\end{array}$ & Ponds, reservoirs, rivers & Herbicides \\
\hline Bufo viridis & Very common and widespread & Ponds, reservoirs, water basins & - \\
\hline Hyla intermedia & $\begin{array}{l}\text { Scarce and decreasing, up } \\
\text { to } 1700 \mathrm{~m}\end{array}$ & $\begin{array}{l}\text { Rivers with reeds, citrus groves and } \\
\text { gardens next to the water }\end{array}$ & $\begin{array}{l}\text { Pollution, habitat loss and alteration, } \\
\text { conversion from old irrigation systems to } \\
\text { modern ones }\end{array}$ \\
\hline $\begin{array}{l}\text { Rana bergeri } \mathrm{x} \text { his- } \\
\text { panica }\end{array}$ & $\begin{array}{l}\text { Common and widespread, up to } \\
1700 \mathrm{~m} \text {, decreasing in the orch- } \\
\text { ards }\end{array}$ & $\begin{array}{l}\text { Rivers, ponds, reservoirs, water } \\
\text { basins, etc. }\end{array}$ & $\begin{array}{l}\text { Pollution, conversion from old irrigation } \\
\text { systems to modern ones }\end{array}$ \\
\hline \multicolumn{4}{|l|}{ Reptilia } \\
\hline Emys trinacris* & $\begin{array}{l}\text { Common, locally decreasing, up } \\
\text { to } 1500 \mathrm{~m}\end{array}$ & $\begin{array}{l}\text { Rivers, ponds, reservoirs, water } \\
\text { basins, etc. }\end{array}$ & $\begin{array}{l}\text { Pollution, habitat loss and alteration, in- } \\
\text { troduction of competitive exotic species }\end{array}$ \\
\hline Testudo hermanni & Rare and local, decreasing & Wood clearings and edges, maquis & Collecting, fires, habitat loss \\
\hline $\begin{array}{l}\text { Hemidactylus } \\
\text { turcicus }\end{array}$ & $\begin{array}{l}\text { Common and widespread, up to } \\
600 \mathrm{~m}\end{array}$ & $\begin{array}{l}\text { Rocky habitats, woods, rural and } \\
\text { urban areas }\end{array}$ & - \\
\hline $\begin{array}{l}\text { Tarentola maurita- } \\
\text { nica }\end{array}$ & $\begin{array}{l}\text { Common and widespread, up to } \\
1250 \mathrm{~m}\end{array}$ & $\begin{array}{l}\text { Rocky habitats, woods, rural and } \\
\text { urban areas }\end{array}$ & - \\
\hline Lacerta bilineata & $\begin{array}{l}\text { Common, but moderately } \\
\text { decreasing, up to } 1850 \mathrm{~m}\end{array}$ & $\begin{array}{l}\text { Maquis, wood edges, areas close to } \\
\text { water, hedgerows }\end{array}$ & Habitat alteration \\
\hline Podarcis filfolensis* & Very common & In Italy only on Pelagian Is. & - \\
\hline Podarcis raffonei* & $\begin{array}{l}\text { Uncommon, some populations } \\
\text { are endangered }\end{array}$ & Only Aeolian Is. & Habitat alteration \\
\hline Podarcis sicula & $\begin{array}{l}\text { Common and widespread, up to } \\
2150 \mathrm{~m}\end{array}$ & $\begin{array}{l}\text { Garrigues, pastures, urban and culti- } \\
\text { vated areas, gardens, wood edges }\end{array}$ & - \\
\hline $\begin{array}{l}\text { Podarcis wagleri- } \\
\text { ana* }\end{array}$ & $\begin{array}{l}\text { Locally common, lacking in NE } \\
\text { Sicily, slightly decreasing, up to } \\
1600 \mathrm{~m}\end{array}$ & $\begin{array}{l}\text { Garrigues, pastures, cultivated areas, } \\
\text { gardens, wood edges }\end{array}$ & Possible local competition with $P$. sicula \\
\hline $\begin{array}{l}\text { Psammodromus al- } \\
\text { girus }\end{array}$ & Scarce & $\begin{array}{l}\text { Only on Scoglio dei Conigli } \\
\text { (Lampedusa Is.) }\end{array}$ & - \\
\hline Chalcides chalcides & Common, up to $1840 \mathrm{~m}$ & $\begin{array}{l}\text { Rural habitats, grassy and sunny } \\
\text { slopes, often next to the water }\end{array}$ & - \\
\hline Chalcides ocellatus & $\begin{array}{l}\text { Common, slightly decreasing, up } \\
\text { to } 1500 \mathrm{~m}\end{array}$ & $\begin{array}{l}\text { Xeric, stony and rural habitats, } \\
\text { pastures }\end{array}$ & Agriculture mechanization \\
\hline $\begin{array}{l}\text { Haemorrhois hippo- } \\
\text { crepis }\end{array}$ & Uncommon & Only on Pantelleria Is. & - \\
\hline $\begin{array}{l}\text { Hierophis viridi- } \\
\text { flavus }\end{array}$ & $\begin{array}{l}\text { Common and widespread, up to } \\
1840 \mathrm{~m}\end{array}$ & $\begin{array}{l}\text { Garrigues, pastures, urban and culti- } \\
\text { vated areas, gardens, wood edges }\end{array}$ & - \\
\hline Coronella austriaca & $\begin{array}{l}\text { Uncommon and local between } \\
800 \text { and } 1700 \mathrm{~m}\end{array}$ & Wood edges, stony habitats & - \\
\hline Elaphe lineata & $\begin{array}{l}\text { Uncommon and local, up to } 1450 \\
\mathrm{~m}\end{array}$ & $\begin{array}{l}\text { Garrigues, pastures, cultivated areas, } \\
\text { wood edges }\end{array}$ & - \\
\hline Elaphe situla & Scarce and local, up to c. $800 \mathrm{~m}$ & Xeric and sandy habitats, pastures & Habitat loss \\
\hline $\begin{array}{l}\text { Macroprotodon cu- } \\
\text { cullatus }\end{array}$ & Uncommon & Only on Lampedusa Is. & - \\
\hline $\begin{array}{l}\text { Malpolon mon- } \\
\text { spessulanus }\end{array}$ & Uncommon & Only on Lampedusa Is. & - \\
\hline Natrix natrix & $\begin{array}{l}\text { Common and widespread, up to } \\
1770 \mathrm{~m}\end{array}$ & $\begin{array}{l}\text { Rivers, reservoirs, ponds, rocky } \\
\text { habitats }\end{array}$ & - \\
\hline Vipera aspis hugyi* & Uncommon, up to $1850 \mathrm{~m}$ & $\begin{array}{l}\text { Stony and rocky habitats, clearings } \\
\text { and wood edges }\end{array}$ & - \\
\hline
\end{tabular}


Tab. 5 - Sicilian terrestrial Mammals and their status in Sicily (excluded Chiroptera and introduced or reintroduced species: Myocastor coypus - only on the mouth of Irminio river -, Ovis aries - only on Marettimo Is. -, Dama dama and Sus scrofa). ${ }^{*}=$ endemic taxa.

\begin{tabular}{|c|c|c|c|}
\hline Species & Status & Habitat & $\begin{array}{l}\text { Factors affecting eventual } \\
\text { decline }\end{array}$ \\
\hline $\begin{array}{l}\text { Erinaceus europaeus con- } \\
\text { solei* }^{*}\end{array}$ & Common and widespread & $\begin{array}{l}\text { Agroecosystems, } \\
\text { hedgerows, woods, etc. }\end{array}$ & $\begin{array}{l}\text { Locally high mortality along busy } \\
\text { roads }\end{array}$ \\
\hline Suncus etruscus & Common below $1000 \mathrm{~m}$ & $\begin{array}{l}\text { Cerealicolous areas, agro- } \\
\text { ecosystems, garrigues, etc. }\end{array}$ & - \\
\hline Crocidura sicula* & $\begin{array}{l}\text { Common and widespread } \\
\text { up to } 1600 \mathrm{~m}\end{array}$ & $\begin{array}{l}\text { Agroecosystems, } \\
\text { hedgerows, woods, etc. }\end{array}$ & $\begin{array}{l}\text { Tillage and pesticides in } \\
\text { agroecosystems }\end{array}$ \\
\hline Crocidura pachyura & Common & Only on Pantelleria Is. & - \\
\hline Oryctolagus cuniculus & $\begin{array}{l}\text { Common and widespread } \\
\text { up to } 1800 \mathrm{~m}\end{array}$ & $\begin{array}{l}\text { Agroecosystems, } \\
\text { hedgerows, woods, etc. }\end{array}$ & $\begin{array}{l}\text { Hunting, virus spread, due also } \\
\text { to introduction of domestic indi- } \\
\text { viduals }\end{array}$ \\
\hline Lepus corsicanus & $\begin{array}{l}\text { Uncommon, locally scarce } \\
\text { and generally declining, } \\
\text { up to } 1800 \mathrm{~m} \text {; set-aside has } \\
\text { favoured local increasing }\end{array}$ & $\begin{array}{l}\text { Agroecosystems, } \\
\text { hedgerows, woods, etc. }\end{array}$ & $\begin{array}{l}\text { Hunting, tillage, passage from ex- } \\
\text { tensive to intensive agriculture }\end{array}$ \\
\hline Eliomys quercinus & Scarce, up to $1600 \mathrm{~m}$ & $\begin{array}{l}\text { Agroecosystems, olive } \\
\text { groves, hedgerows, woods, } \\
\text { etc. }\end{array}$ & $\begin{array}{l}\text { Cutting of old olives, fires, com- } \\
\text { petition with rats in rural areas }\end{array}$ \\
\hline Glis glis & $\begin{array}{l}\text { Scarce and local, up to } 1500 \\
\mathrm{~m}\end{array}$ & Woods & $\begin{array}{l}\text { Fires, cutting of chestnut woods } \\
\text { and abandonment of hazel } \\
\text { groves, poaching }\end{array}$ \\
\hline Muscardinus avellanarius & $\begin{array}{l}\text { Scarce and local between } 800 \\
\text { and } 1600 \mathrm{~m}\end{array}$ & Woods & $\begin{array}{l}\text { Fires, cutting of chestnut woods } \\
\text { and abandonment of hazel } \\
\text { groves, poaching in particular of } \\
\text { undergrowth }\end{array}$ \\
\hline Microtus savii & $\begin{array}{l}\text { Very common and wide- } \\
\text { spread, up to } 1800 \mathrm{~m}\end{array}$ & $\begin{array}{l}\text { Agroecosystems, wood } \\
\text { clearings and edges }\end{array}$ & - \\
\hline Rattus rattus & $\begin{array}{l}\text { Very common and wide- } \\
\text { spread, up to } 1600 \mathrm{~m}\end{array}$ & $\begin{array}{l}\text { Rural areas, villages, towns, } \\
\text { woods }\end{array}$ & - \\
\hline Rattus norvegicus & $\begin{array}{l}\text { Very common and wide- } \\
\text { spread, up to } 1200 \mathrm{~m}\end{array}$ & $\begin{array}{l}\text { Houses sewage systems, } \\
\text { rivers next to towns and vil- } \\
\text { lages, etc. }\end{array}$ & - \\
\hline Mus domesticus & $\begin{array}{l}\text { Very common and wide- } \\
\text { spread, up to } 1000 \mathrm{~m}\end{array}$ & $\begin{array}{l}\text { Rural areas, houses, vil- } \\
\text { lages, towns, etc. }\end{array}$ & - \\
\hline Apodemus sylvaticus & $\begin{array}{l}\text { Common and widespread, } \\
\text { up to } 1800 \mathrm{~m}\end{array}$ & $\begin{array}{l}\text { Agroecosystems, groves, } \\
\text { woods, etc. }\end{array}$ & - \\
\hline Hystrix cristata & $\begin{array}{l}\text { Local and uncommon up to } \\
1600 \mathrm{~m}\end{array}$ & $\begin{array}{l}\text { Maquis, garrigues, rocky } \\
\text { areas, woods }\end{array}$ & Poaching, habitat loss \\
\hline Vulpes vulpes & $\begin{array}{l}\text { Common and widespread, } \\
\text { up to } 2000 \mathrm{~m}\end{array}$ & $\begin{array}{l}\text { Agroecosystems, woods, } \\
\text { urban edges and gardens }\end{array}$ & - \\
\hline Martes martes & $\begin{array}{l}\text { Uncommon, locally increas- } \\
\text { ing, up to } 1800 \mathrm{~m}\end{array}$ & Woods and cultivated areas & $\begin{array}{l}\text { Poaching, dead individuals fre- } \\
\text { quently found along busy roads }\end{array}$ \\
\hline Mustela nivalis & $\begin{array}{l}\text { Common and widespread, } \\
\text { up to } 2000 \mathrm{~m} \text { but in orchard } \\
\text { declining probably caused } \\
\text { by directly or indirectly pol- } \\
\text { lution }\end{array}$ & $\begin{array}{l}\text { Agroecosystems, } \\
\text { hedgerows, woods, urban } \\
\text { gardens, etc. }\end{array}$ & $\begin{array}{l}\text { High mortality observed along } \\
\text { busy roads }\end{array}$ \\
\hline Felis silvestris & Local, up to $1800 \mathrm{~m}$ & Woods and rocky areas & Poaching, habitat loss \\
\hline
\end{tabular}


vestris, because of its habitat loss and eventual crossbreeding with feral cats (Sarà 1998). Wood management, particularly the cutting of chestnut woods, the conversion from high forest to coppices (La Mantia et al. 1999), abandonment of hazel groves may seriously affect populations of Glis glis and mainly Muscardinus avellanarius, due to bushes removal and undergrowth clearing, vegetal layers consenting them to move among trees, without going down to the ground (Sarà 1998). Furthermore, the expansion of Rattus species may affect competitively other small mammals, like Gliridae. The hare (Lepus corsicanus), living other than in Sicily in the central and southern Apennines and Corsica, have undergone a drastic decline in the '80s, likely to be due to pesticides and fertilizers use in agriculture, but since the '90s it has locally shown an increase, possibly due to the application of agri-environmental regulations and the consequent reduction of pesticides spreading. The introduction of allochthonous species (Lepus europaeus) seems unsuccessful so far (Lo Valvo et al. 1997). Forestation is considered a danger for the species, especially if carried out with allochthonous species (Trocchi \& Riga 2001).

Hunting and poaching are local causes of species decline, and a better hunting management is warmly required. Finally, only some Rodents are noxious to agriculture; among them Microtus savii is considered a local pest to horticulture and in some cases to orchards (Massa \& Lo Verde 2007).

\section{Current status of terrestrial birds in Sicily}

Overall, 106 terrestrial birds breed regularly in Sicily, most of which are linked to grasslands (24.5\%), rocky habitats $(23.5 \%)$, and woodlands (32.1\%) (Tab. 6). Most birds live in grasslands or use this habitat secondarily. Out of 26 species associated with it, 11 have stable populations, four are in small decline, four in large decline, five in small increase and two in large increase. Total intrinsic value of birds living in grasslands is 24.15. Seven species lie in the Spec2 category, 14 in Spec3, and one in NonSpec ${ }^{\mathrm{E}}$, four species are endangered and five are at lower risk as breeders in Italy.

The most important habitats for birds, together with grasslands, are rocky areas. Often birds living in this habitat also exploit grassland resources, occurring both in rocky and in grassland habitats. 25 species live in rocky areas or secondarily use this habitat; 12 have stable populations, seven are in small increase, four in small decline, two in large decline. One species is listed as Spec1, two as Spec2 and NonSpec ${ }^{\mathrm{E}}$ categories, 10 as Spec3, two species are critically endangered, two endangered, six vulnerable and six at lower risk in Italy. Total intrinsic value of birds living in rocky habitats is 26.15 . Altogether, birds living in the previous two habitats represent the most important component of the Sicilian avifauna, amounting to the total intrinsic value of 50.30 (total value for all Sicilian terrestrial breeding birds is 70.25).

Few bird species (eight on the total) are more or less strictly associated with the maquis; they have stable populations, two species lie in Spec2, one in Spec3 categories and four in NonSpec ${ }^{\mathrm{E}}$, no species are listed as threatened in Italy.

Finally, 34 species are linked to woodlands, 16 of which are stable, 16 in small increase and two in large increase; no species living in this kind of habitat has shown some decline in the last decades. Only one species is found in the Spec2, four in Spec3, 14 in NonSpec ${ }^{\mathrm{E}}$, one species is critically endangered, two are vulnerable and three are at lower risk; the total intrinsic value of birds living in this habitat is 10.45 , showing the modest presence of conservation concern species.

\section{Declining selected species of agroecosystems}

Milvus milvus. Greatly declining for at least 15 years, its population has decreased of $80 \%$, from 90 to less than 15 pairs. It occurs in extensive agroecosystems, pastures and sowable grounds, mainly within an area where the percentage application of RDP on UAS is remarkable (range: 4.08-14.71\%).

Milvus migrans. Migrant breeder and wintering, it colonized Sicily at the end of the '70s (Massa 1980), occurring mainly on rocky habitats, pastures and sowable grounds. Its sedentarization in Sicily could depend on the application of agri-environment regulations, but recently has declined.

Neophron percnopterus. Fluctuating, it decreased quickly in the '90s from 20 to 3-4 pairs, but in the last years it increased again to 7-8 pairs, due to its breeding success (most pairs fledged two chicks); being a migratory bird, abiotic factors bringing about its fluctuation and decrease could take place outside Sicily. Massi et al. (1990), in the case of two dead vultures found in the Calabria region, report that large amounts of DDT and its metabolites were found in their tissues. Marsili \& Massi (1991) recorded two individuals dead on a sicilian nest in 1990, possibly for the ingestion of poisoned baits. Recent small positive fluctuation may be due to effects of agri-environment policy; good overlapping of sicilian popula- 
Tab. 6 - Terrestrial sicilian breeding birds in selected habitats.

\begin{tabular}{|c|c|c|c|c|c|c|c|c|c|c|}
\hline Scientific name & Habitat & $79 / 409$ & $\begin{array}{l}\text { Status in } \\
\text { Europe }\end{array}$ & $\begin{array}{l}\text { Italian } \\
\text { Red } \\
\text { List }\end{array}$ & $\begin{array}{c}\text { Trend } \\
\text { in Italy } \\
(1970- \\
1990)\end{array}$ & $\begin{array}{c}\text { Trend } \\
\text { in Italy } \\
(1990- \\
2000)\end{array}$ & $\begin{array}{l}\text { Trend in } \\
\text { Sicily } \\
\text { (1979- } \\
\text { 1992) }\end{array}$ & $\begin{array}{l}\text { Trend in } \\
\text { Sicily } \\
(1993- \\
2006)\end{array}$ & $\begin{array}{c}\text { Intrinsic } \\
\text { value }\end{array}$ & $\begin{array}{c}\Sigma \\
\text { (intrinsic } \\
\text { value) } \\
\text { per } \\
\text { habitat } \\
\end{array}$ \\
\hline 1. Sturnus vulgaris & $\begin{array}{l}\text { Arboreous and urban } \\
\text { areas }\end{array}$ & - & SPEC3 & - & 0 & +1 & +1 & 0 & 0.5 & \multirow{4}{*}{1.0} \\
\hline 2. Passer hispaniolensis & $\begin{array}{l}\text { Arboreous and urban } \\
\text { areas }\end{array}$ & - & - & - & 0 & 0 & 0 & 0 & 0 & \\
\hline 3. Passer montanus & $\begin{array}{l}\text { Arboreous and urban } \\
\text { areas }\end{array}$ & - & SPEC3 & - & 0 & -1 & +1 & 0 & 0.5 & \\
\hline 4. Corvus cornix & $\begin{array}{l}\text { Arboreous and urban } \\
\text { areas }\end{array}$ & - & - & - & 0 & 0 & 0 & 0 & 0 & \\
\hline 5. Falco eleonorae & Cliffs on small islands & + & SPEC2 & VU & 0 & 0 & 0 & 0 & 2.15 & 2.15 \\
\hline 6. Ciconia ciconia & Grasslands & + & SPEC2 & LR & +2 & +1 & +1 & +2 & 1.95 & \multirow{26}{*}{24.15} \\
\hline 7. Coturnix coturnix & Grasslands & - & SPEC3 & LR & -1 & $?$ & -2 & 0 & 0.7 & \\
\hline 8. Burhinus oedicnemus & Grasslands & + & SPEC3 & EN & -1 & -1 & -1 & 0 & 2.1 & \\
\hline 9. Merops apiaster & Grasslands & - & SPEC3 & - & 0 & +1 & +1 & +2 & 0.5 & \\
\hline 10. Coracias garrulus & Grasslands & + & SPEC2 & EN & -1 & 0 & -2 & -2 & 2.35 & \\
\hline $\begin{array}{l}\text { 11. Melanocorypha } \\
\text { calandra }\end{array}$ & Grasslands & + & SPEC3 & LR & -1 & -1 & -2 & -2 & 1.7 & \\
\hline $\begin{array}{l}\text { 12. Calandrella } \\
\text { brachydactyla }\end{array}$ & Grasslands & + & SPEC3 & - & 0 & -1 & -1 & -1 & 1.5 & \\
\hline 13. Galerida cristata & Grasslands & - & SPEC3 & - & -1 & 0 & 0 & 0 & 0.5 & \\
\hline 14. Alauda arvensis & Grasslands & - & SPEC3 & - & -1 & -1 & -2 & 0 & 0.5 & \\
\hline 15. Anthus campestris & Grasslands & - & SPEC3 & - & -1 & -1 & 0 & -1 & 0.5 & \\
\hline 16. Saxicola torquatus & Grasslands & - & - & - & +1 & 0 & 0 & 0 & 0 & \\
\hline 17. Cisticola juncidis & Grasslands & - & - & - & 0 & 0 & 0 & +1 & 0 & \\
\hline 18. Sylvia conspicillata & Grasslands & - & - & - & 0 & $?$ & 0 & 0 & 0.25 & \\
\hline 19. Emberiza calandra & Grasslands & - & SPEC2 & - & -1 & -1 & 0 & 0 & 0.75 & \\
\hline 20. Otus scops & $\begin{array}{l}\text { Grasslands and } \\
\text { arboreous areas }\end{array}$ & - & SPEC2 & LR & -1 & -1 & -1 & 0 & 0.95 & \\
\hline 21. Glareola pratincola & $\begin{array}{l}\text { Grasslands and humid } \\
\text { areas }\end{array}$ & + & SPEC3 & EN & 0 & 0 & -1 & 0 & 2.1 & \\
\hline 22. Motacilla flava & $\begin{array}{l}\text { Grasslands and humid } \\
\text { areas }\end{array}$ & - & - & - & 0 & 0 & +1 & -1 & 0 & \\
\hline 23. Hirundo rustica & $\begin{array}{l}\text { Grasslands and urban } \\
\text { areas }\end{array}$ & - & SPEC3 & - & -1 & 0 & 0 & +1 & 0.5 & \\
\hline 24. Delichon urbicum & $\begin{array}{l}\text { Grasslands and urban } \\
\text { areas }\end{array}$ & - & SPEC3 & - & 0 & 0 & +1 & +1 & 0.5 & \\
\hline 25. Sturnus unicolor & $\begin{array}{l}\text { Grasslands and urban } \\
\text { areas }\end{array}$ & - & NonSPEC $^{\mathrm{E}}$ & - & 0 & 0 & +1 & +1 & 0.25 & \\
\hline 26. Lullula arborea & $\begin{array}{l}\text { Grasslands and wood } \\
\text { edges }\end{array}$ & + & SPEC2 & - & 0 & 0 & 0 & 0 & 1.75 & \\
\hline 27. Streptopelia turtur & Grasslands and woods & - & SPEC3 & - & 0 & 0 & 0 & 0 & 0.5 & \\
\hline 28. Athene noctua & $\begin{array}{l}\text { Grasslands, with } \\
\text { scattered trees }\end{array}$ & - & SPEC3 & - & 0 & 0 & 0 & 0 & 0.5 & \\
\hline 29. Lanius senator & $\begin{array}{l}\text { Grasslands, with } \\
\text { scattered trees }\end{array}$ & - & SPEC2 & LR & -1 & -1 & -1 & -1 & 0.95 & \\
\hline 30. Lanius collurio & $\begin{array}{l}\text { Grasslands, with } \\
\text { scattered shrubs }\end{array}$ & - & SPEC3 & - & -1 & -1 & -1 & -1 & 0.5 & \\
\hline 31. Lanius minor & $\begin{array}{l}\text { Grasslands, with } \\
\text { scattered trees }\end{array}$ & + & SPEC2 & EN & -1 & -1 & -1 & -2 & 2.35 & \\
\hline $\begin{array}{l}\text { 32. Acrocephalus } \\
\text { scirpaceus }\end{array}$ & Humid areas & - & NonSPEC $^{\mathrm{E}}$ & - & -1 & 0 & 0 & 0 & 0.25 & \multirow{2}{*}{0.25} \\
\hline $\begin{array}{l}\text { 33. Acrocephalus } \\
\text { arundinaceus }\end{array}$ & Humid areas & - & - & - & -1 & -1 & -2 & -1 & 0 & \\
\hline
\end{tabular}


Tab. 6 (continued) - Terrestrial sicilian breeding birds in selected habitats.

\begin{tabular}{|c|c|c|c|c|c|c|c|c|c|c|}
\hline Scientific name & Habitat & $79 / 409$ & $\begin{array}{l}\text { Status in } \\
\text { Europe }\end{array}$ & $\begin{array}{c}\text { Italian } \\
\text { Red } \\
\text { List }\end{array}$ & $\begin{array}{c}\text { Trend } \\
\text { in Italy } \\
(1970- \\
1990)\end{array}$ & $\begin{array}{c}\text { Trend } \\
\text { in Italy } \\
(1990- \\
2000)\end{array}$ & $\begin{array}{c}\text { Trend in } \\
\text { Sicily } \\
\text { (1979- } \\
\text { 1992) }\end{array}$ & $\begin{array}{c}\text { Trend } \\
\text { in Sicily } \\
(1993- \\
2006)\end{array}$ & $\begin{array}{l}\text { Intrinsi } \\
\text { c value }\end{array}$ & $\begin{array}{c}\Sigma \\
\text { (intrinsic } \\
\text { value) } \\
\text { per } \\
\text { habitat }\end{array}$ \\
\hline 34. Sylvia cantillans & Maquis & - & NonSPEC $^{\mathrm{E}}$ & - & 0 & 0 & 0 & 0 & 0.25 & \\
\hline 35. Sylvia communis & Maquis & - & NonSPEC ${ }^{\mathrm{E}}$ & - & 0 & 0 & 0 & 0 & 0.25 & \\
\hline 36. Sylvia undata & Maquis & + & SPEC2 & - & 0 & 0 & 0 & 0 & 1.75 & \\
\hline 37. Sylvia melanocephala & Maquis and gardens & - & NonSPEC $^{\mathrm{E}}$ & - & 0 & 0 & 0 & +1 & 0.25 & 40 \\
\hline 38. Carduelis carduelis & Maquis and Grasslands & - & - & - & 0 & 0 & 0 & +1 & 0 & 4.0 \\
\hline 39. Carduelis cannabina & Maquis and Grasslands & - & SPEC2 & - & 0 & 0 & 0 & 0 & 0.75 & \\
\hline 40. Emberiza cirlus & Maquis and Grasslands & - & NonSPEC $^{\mathrm{E}}$ & - & 0 & 0 & +1 & 0 & 0.25 & \\
\hline 41. Emberiza cia & Maquis and rocky areas & - & SPEC3 & - & -1 & 0 & 0 & 0 & 0.5 & \\
\hline 42. Remiz pendulinus & Rivers and humid areas & - & - & - & +1 & +1 & +1 & +1 & 0 & \\
\hline 43. Motacilla cinerea & Rivers and urban areas & - & - & - & 0 & 0 & 0 & 0 & 0 & \\
\hline 44. Motacilla alba & Rivers and urban areas & - & - & - & -1 & 0 & 0 & 0 & 0 & 0 \\
\hline 45. Cettia cetti & $\begin{array}{l}\text { Rivers, humid areas, } \\
\text { maquis }\end{array}$ & - & - & - & +1 & 0 & 0 & 0 & 0 & \\
\hline 46. Apus pallidus & Rocky and urban areas & - & - & LR & +1 & 0 & +1 & +1 & 0.2 & \\
\hline 47. Apus apus & Rocky and urban areas & - & - & - & 0 & 0 & 0 & 0 & 0 & \\
\hline 48. Corvus monedula & Rocky and urban areas & - & NonSPEC ${ }^{\mathrm{E}}$ & - & +1 & 0 & +1 & +1 & 0.25 & \\
\hline 49. Milvus milvus & Rocky areas & + & SPEC2 & EN & -1 & 0 & -2 & -2 & 2.35 & \\
\hline 50. Milvus migrans & Rocky areas & + & SPEC3 & VU & 0 & 0 & 0 & -1 & 1.9 & \\
\hline $\begin{array}{l}\text { 51. Neophron } \\
\text { percnopterus }\end{array}$ & Rocky areas & + & SPEC3 & $\mathrm{CR}$ & -2 & -2 & -2 & -1 & 2.3 & \\
\hline 52. Aquila chrysaetos & Rocky areas & + & SPEC3 & VU & 0 & 0 & +1 & 0 & 1.9 & \\
\hline 53. Hieraaetus fasciatus & Rocky areas & + & SPEC3 & $\mathrm{CR}$ & -1 & -1 & -1 & -1 & 2.3 & \\
\hline 54. Falco tinnunculus & Rocky areas & - & SPEC3 & - & -1 & +1 & 0 & +1 & 0.5 & \\
\hline 55. Falco biarmicus & Rocky areas & + & SPEC3 & EN & -1 & -1 & 0 & 0 & 2.1 & \\
\hline 56. Falco peregrinus & Rocky areas & + & - & VU & -1 & +4 & +1 & +1 & 1.9 & \\
\hline 57. Alectoris graeca & Rocky areas & + & SPEC2 & VU & -1 & -1 & $\begin{array}{c}-1 \\
\text { whitakeri }\end{array}$ & $\begin{array}{c}-2 \\
\text { whitakeri }\end{array}$ & 2.15 & \\
\hline 58. Tyto alba & Rocky areas & + & SPEC3 & LR & -1 & -1 & 0 & +1 & 1.7 & \\
\hline 59. Apus melba & Rocky areas & - & - & LR & 0 & 0 & 0 & 0 & 0.2 & 26.15 \\
\hline $\begin{array}{l}\text { 60. Ptyonoprogne } \\
\text { rupestris }\end{array}$ & Rocky areas & - & - & - & 0 & 0 & -1 & 0 & 0 & \\
\hline 61. Oenanthe oenanthe & Rocky areas & - & SPEC3 & - & 0 & -1 & 0 & 0 & 0.5 & \\
\hline 62. Monticola saxatilis & Rocky areas & - & SPEC3 & LR & -1 & -1 & 0 & 0 & 0.7 & \\
\hline 63. Monticola solitarius & Rocky areas & - & SPEC3 & - & -1 & 0 & 0 & 0 & 0.5 & \\
\hline $\begin{array}{l}\text { 64. Pyrrhocorax } \\
\text { pyrrhocorax }\end{array}$ & Rocky areas & + & SPEC3 & VU & -2 & 0 & -2 & -1 & 1.9 & \\
\hline 65. Corvus corax & Rocky areas & - & - & LR & 0 & 0 & 0 & -1 & 0.2 & \\
\hline 66. Petronia petronia & Rocky areas & - & - & - & -1 & 0 & 0 & 0 & 0 & \\
\hline 67. Falco naumanni & $\begin{array}{l}\text { Rocky areas and grass- } \\
\text { lands }\end{array}$ & + & SPEC1 & LR & -1 & +2 & -1 & 0 & 2.20 & \\
\hline 68. Columba livia & $\begin{array}{l}\text { Rocky areas and grass- } \\
\text { lands }\end{array}$ & - & - & VU & No data & 0 & 0 & +1 & 0.4 & \\
\hline 69. Buteo buteo & Rocky areas and woods & - & - & - & -1 & +1 & 0 & 0 & 0 & \\
\hline 70. Phoenicurus ochruros & socky areas and woods & - & - & - & 0 & 0 & 0 & 0 & 0 & \\
\hline
\end{tabular}

tions of this species and those of Milvus milvus should corroborate this hypothesis.

Alectoris graeca whitakeri. The only thriving populations of this endemic taxon live in the Natural Parks and some Nature Reserves. It feeds on erbaceous plants, leaves, flowers, inflorescences, fruits, bulbs, seeds, in summer preferring insects, as ants, beetles, grasshoppers, etc. (Lo Valvo et al. 1993). Set aside of sowable grounds had certainly positive effects on its populations, partially frustrated by hunting activity and poaching, main reasons of its decline.

Burhinus oedicnemus. Declining since many decades in some Italian regions, populations breeding in $\mathrm{Si}$ cily are strictly linked to grasslands characterized by stony pastures, often far from rivers; even if locally increasing (e.g., in the Gela plain and along the Salso 
Tab. 6 (continued) - Terrestrial sicilian breeding birds in selected habitats.

\begin{tabular}{|c|c|c|c|c|c|c|c|c|c|c|c|}
\hline $\mathbf{N}^{\circ}$ & Scientific name & Habitat & $79 / 409$ & $\begin{array}{l}\text { Status in } \\
\text { Europe }\end{array}$ & $\begin{array}{c}\text { Italian } \\
\text { Red } \\
\text { List }\end{array}$ & $\begin{array}{c}\text { Trend } \\
\text { in Italy } \\
(1970- \\
1990)\end{array}$ & $\begin{array}{c}\text { Trend } \\
\text { in Italy } \\
(1990- \\
2000)\end{array}$ & $\begin{array}{c}\text { Trend } \\
\text { in Sicily } \\
(1979- \\
1992)\end{array}$ & $\begin{array}{c}\text { Trend } \\
\text { in Sicily } \\
(1993- \\
2006)\end{array}$ & $\begin{array}{c}\text { Intrinsic } \\
\text { value }\end{array}$ & $\begin{array}{c}\Sigma \\
\text { (intrinsic } \\
\text { value) } \\
\text { per } \\
\text { habitat }\end{array}$ \\
\hline 71. & Circaetus gallicus & Scattered trees on hills & + & SPEC3 & EN & -1 & 0 & $0^{*}$ & 0 & 2.1 & 2.1 \\
\hline 72. & $\begin{array}{l}\text { Streptopelia de- } \\
\text { caocto }\end{array}$ & $\begin{array}{l}\text { Urban and cultivated } \\
\text { areas }\end{array}$ & - & - & - & +1 & +1 & +1 & +2 & 0 & 0 \\
\hline 73. & Columba palumbus & Woods and urban areas & - & NonSPEC $^{\mathrm{E}}$ & - & +1 & +1 & +2 & +2 & 0.25 & \\
\hline 74. & Accipiter nisus & Woods & + & - & - & 0 & +1 & 0 & +1 & 1.0 & \\
\hline 75. & Falco subbuteo & Woods & - & - & VU & -1 & +1 & 0 & +1 & 0.4 & \\
\hline 76. & Cuculus canorus & Woods & - & - & - & 0 & 0 & 0 & 0 & 0 & \\
\hline 77. & Asio otus & Woods & - & - & LR & 0 & 0 & +1 & +1 & 0.2 & \\
\hline 78. & Strix aluco & Woods & - & NonSPEC $^{\mathrm{E}}$ & - & -1 & 0 & 0 & 0 & 0.25 & \\
\hline 79. & $\begin{array}{l}\text { Caprimulgus euro- } \\
\text { paeus }\end{array}$ & Woods & + & SPEC2 & LR & -1 & -1 & 0 & 0 & 1.95 & \\
\hline 80. & Jynx torquilla & Woods & - & SPEC3 & - & -1 & -1 & +1 & 0 & 0.5 & \\
\hline 81. & Dendrocopos major & Woods & - & - & - & -1 & 0 & +1 & +2 & 0 & \\
\hline 82. & $\begin{array}{l}\text { Luscinia } \\
\text { megarhynchos }\end{array}$ & Woods & - & NonSPEC $^{\mathrm{E}}$ & - & +1 & 0 & 0 & 0 & 0.25 & \\
\hline 83. & Turdus viscivorus & Woods & - & NonSPEC $^{\mathrm{E}}$ & - & -1 & -1 & 0 & 0 & 0.25 & \\
\hline 84. & Aegithalos caudatus & Woods & - & - & LR & 0 & 0 & 0 siculus & 0 siculus & 0.2 & \\
\hline 85. & Poecile palustris & Woods & - & SPEC3 & $\mathrm{CR}$ & 0 & $?$ & 0 siculus & 0 siculus & 1.3 & \\
\hline 86. & Periparus ater & Woods & - & - & - & 0 & $?$ & 0 & +1 & 0 & \\
\hline 87. & Cyanistes caeruleus & Woods & - & NonSPEC $^{\mathrm{E}}$ & - & 0 & 0 & 0 & 0 & 0.25 & \\
\hline 88. & Sitta europaea & Woods & - & - & - & -1 & 0 & 0 & 0 & 0 & \\
\hline 89. & Carduelis spinus & Woods & - & NonSPEC ${ }^{\mathrm{E}}$ & VU & 0 & 0 & 0 & 0 & 0.65 & \\
\hline 90. & Loxia curvirostra & Woods & - & - & - & No data & 0 & +1 & 0 & 0 & \\
\hline 91. & Garrulus glandarius & $\begin{array}{l}\text { Woods and arboreous } \\
\text { area }\end{array}$ & & & & & & & & & 10.45 \\
\hline 92. & Upupa epops & $\begin{array}{l}\text { Woods and arboreous } \\
\text { areas }\end{array}$ & - & SPEC3 & - & 0 & $?$ & +1 & +1 & 0.5 & \\
\hline 93. & Oriolus oriolus & $\begin{array}{l}\text { Woods and arboreous } \\
\text { areas }\end{array}$ & - & - & - & 0 & 0 & 0 & 0 & 0 & \\
\hline 94. & $\begin{array}{l}\text { Troglodytes troglo- } \\
\text { dytes }\end{array}$ & Woods and gardens & - & - & - & 0 & 0 & +1 & +1 & 0 & \\
\hline 95. & Erithacus rubecula & Woods and gardens & - & NonSPEC $^{\mathrm{E}}$ & - & 0 & 0 & +1 & +1 & 0.25 & \\
\hline 96. & Turdus merula & Woods and gardens & - & NonSPEC ${ }^{\mathrm{E}}$ & - & +1 & +1 & +2 & +1 & 0.25 & \\
\hline 97. & Sylvia atricapilla & Woods and gardens & - & NonSPEC ${ }^{\mathrm{E}}$ & - & 0 & 0 & 0 & +1 & 0.25 & \\
\hline 98. & $\begin{array}{l}\text { Phylloscopus colly- } \\
\text { bita }\end{array}$ & Woods and gardens & - & - & - & 0 & 0 & 0 & +1 & 0 & \\
\hline 99. & Regulus ignicapilla & Woods and gardens & - & NonSPEC $^{\mathrm{E}}$ & - & 0 & 0 & +1 & +1 & 0.25 & \\
\hline 100. & Muscicapa striata & Woods and gardens & - & SPEC3 & - & 0 & 0 & +1 & +1 & 0.5 & \\
\hline 101. & Parus major & Woods and gardens & - & - & - & 0 & 0 & 0 & 0 & 0 & \\
\hline 102. & $\begin{array}{l}\text { Certhia brachydac- } \\
\text { tyla }\end{array}$ & Woods and gardens & - & NonSPEC $^{\mathrm{E}}$ & - & 0 & 0 & +1 & 0 & 0.25 & \\
\hline 103. & Pica pica & Woods and gardens & - & - & - & 0 & +1 & +2 & +2 & 0 & \\
\hline 104. & Fringilla coelebs & Woods and gardens & - & NonSPEC ${ }^{\mathrm{E}}$ & - & 0 & 0 & 0 & -1 & 0.25 & \\
\hline 105. & Serinus serinus & Woods and gardens & - & NonSPEC ${ }^{\mathrm{E}}$ & - & +1 & +1 & +1 & +1 & 0.25 & \\
\hline 106. & Carduelis chloris & Woods and gardens & - & NonSPEC $^{\mathrm{E}}$ & - & 0 & +1 & 0 & +1 & 0.25 & \\
\hline
\end{tabular}

river), the conservation of the whole Sicilian populations may dependent on the application of agri-environment regulations.

Glareola pratincola. Although this migrant breeder is generally linked to salty habitats, it has a rich population in the sowable grounds of Gela plain (Caltanissetta - Mascara \& Sarà 2007), and may be con- sidered a local indicator of eco-compatible management of agroecosystems.

Coracias garrulus. Very threatened species (Mascara \& Sarà 2007), it decreased in Italy since 30 years; no persuading reasons of its decline are currently known. We may hypothesize that it is mainly due to the disappearance of dry almonds, often selected as 
Tab. 6 (continued) - Terrestrial sicilian breeding birds in selected habitats (Legend).

Habitat. arboreous areas; cliffs on small islands; cultivated areas; gardens; grasslands; humid areas; maquis; rivers; rocky areas; urban areas; woods.

79/409 Directive (also known as "Birds Directive"). Cited in the Appendix I (updated with 91/244 Directive), listing bird species for which special measures of conservation are needed.

Status in Europe. SPEC1 = species of global conservation concern; SPEC2 = unfavourable conservation status and concentrated in Europe; SPEC3 = unfavourable conservation status and not concentrated in Europe; NonSpecE = favourable conservation status, but concentrated in Europe (= SPEC4 in Tucker \& Heath 1994 - from Birdlife International 2004).

Italian Red List of breeding birds. $\mathrm{EX}=$ Extinct; $\mathrm{CR}=$ critically endangered; $\mathrm{EN}=$ endangered; $\mathrm{VU}=\mathrm{Vulnerable} ; \mathrm{LR}=$ at lower risk (from LIPU \& WWF 1998).

Trend in Sicily (1979-1992). Overall population trend for the 1984-1992; period: $0=$ stable; $-1=$ small decrease, lower than $50 \%$; $-2=$ large decrease, higher than $50 \%$; +1 = small increase, lower than $50 \% ;+2=$ large increase, higher than $50 \%$ (from Lo Valvo et al. 1993; ${ }^{*}=$ unpublished data).

Trend in Sicily (1993-2006). Overall population trend for the 1993-2006; period: $0=$ stable; $-1=$ small decrease, lower than $50 \%$; -2 = large decrease, higher than $50 \%$; +1 = small increase, lower than $50 \% ;+2=$ large increase, higher than $50 \%$ (unpublished data).

Trend in Italy (1970-1990). Overall population trend for the 1970-1990 period: $0=$ stable; $-1=$ small decrease, lower than $50 \%$; -2 = large decrease, higher than $50 \% ;+1=$ small increase, lower than $50 \% ;+2=$ large increase, higher than $50 \%$ (from Tallone G, Gustin M, Lambertini M, Meschini E, Brichetti P, Fraissinet M, Gallo-Orsi U, in Heath et al. 2000).

Trend in Italy (1990-2000). Overall population trend for the 1990-2000 period: $0=$ stable; $-1=$ decreasing (overall change $0-19 \%$ ); $-3=$ decreasing (overall change $20-29 \%$ ) $;+1=$ increasing (overall change $0-19 \%$ ) $;+2=$ increasing (overall change 20-29\%); +3 = increasing (overall change 30-49\%); +4 = increasing (overall change 50-79\%); ? = unknown data (from Gustin M \& Brichetti P, in Birdlife International 2004).

Intrinsic value. $\Sigma\left(\right.$ Spec1-NonSpec $\left.{ }^{\mathrm{E}}\right)+(\mathrm{RL})+(409)$, where (Spec1-NonSpec $\left.{ }^{\mathrm{E}}\right)$ are the Spec1-NonSpec ${ }^{\mathrm{E}}$ according to BirdLife International (2004), being Spec1 $=1$, Spec2 $=0.75$, Spec3 $=0.50$, NonSpec $^{\mathrm{E}}=0.25$; (RL) are the species included in the Italian Red List, according to LIPU \& WWF (1998), being EX (breeding extinct species) = 1, CR (critically endangered) = $0.80, \mathrm{EN}($ endangered $)=0.60, \mathrm{VU}($ vulnerable $)=0.40, \mathrm{LR}($ at lower risk $)=0.20 ; 409$ (species listed in the Appendix 1 of $79 / 409$ Directive) $=1$.

breeding habitat.

Melanocorypha calandra. It is one of the most threatened species, probably on verge of extinction, breeding in the Sicilian grassland, often occurring on pastures and ploughed land; formerly it was also recorded as winter visitor (Iapichino \& Massa 1989). Its decline is probably related to cerealiculture changes, selection of new wheat types, of shorter height and early ripening, and, thanks to more advanced threshing machines, to a greater exploitation of straw, cutting it early and close to the ground. Because the breeding cycle of this species actually lies within the season of wheat threshing and straw cutting, its future is very precarious outside areas subjected to setaside rules.

Calandrella brachydactyla. Less threatened than the previous species, in the last decades it was quickly declining in wide cereal cultivations, possibly as effect of mechanization changes, as above quoted. This hypothesis seems supported by the presence of consistent nuclei in areas where the agricultural activity is absent, like Pantelleria airport.
Lanius spp. Three species of shrikes breed in Sicily, of which only one (Lanius senator) today is still more or less scattered on grasslands characterized by the presence of trees, as almonds, carobs, olives, etc. However, it has declined a lot, for rather unknown reasons, as in other European countries (Lefranc 1993). The decrease of $L$. senator and mainly of $L$. minor (now on verge of extinction in Sicily) could be attributed to the disappearance of dried almonds that made part of their breeding habitat.

The disappearance of L. senator on citrus orchards in Palermo, where it was a very common species, is possibly due to the introduction of pesticides and to a general decline of the species itself (La Mantia 1985).

\section{Increasing selected species of agroecosystems}

Ciconia ciconia. Even if this species is more or less linked to resources living in water, often it preys on insects, lizards and small mammals living in dry grasslands, sometimes many kilometres far from water bodies. Sicilian population has increased very 
Tab. 7 - Some suggested changes for Sicilian afforestation and wood managing in order to reduce the impact to fauna.

\begin{tabular}{ll}
\hline Forest & Proposed changes \\
\hline Afforestation & $\begin{array}{l}\text { Only autochthonous species; Plants coming from "plants mothers" as much close } \\
\text { as possible; Plantation sparse with clearing; Hole planting; Preferably ex cultivation } \\
\text { land or degraded area }\end{array}$ \\
Allochthonous wood & $\begin{array}{l}\text { Forest assessment planning; Renaturation of unproductive wood; Sustainable forest } \\
\text { harvesting } \\
\text { Autochthonous wood }\end{array}$ \\
& $\begin{array}{l}\text { Forest assessment planning; Safeguards of the traditional techniques of use (conser- } \\
\text { vation of coppices); Planning of conversion of coppices to high forest; Sustainable } \\
\text { forest harvesting }\end{array}$ \\
\hline
\end{tabular}

much in the last decade, from 2-4 to over 30 breeding pairs, which are becoming more and more sedentary. Giglioli (1886) recorded the possibility of their wintering in Sicily. Its increasing is in accordance with the growth of central and south-eastern Europe (Araùjo \& Bibier 1997) and Tunisia populations (Azafzaf 2002).

Falco naumanni. Even if considered decreasing in the 1970-1990 period (Tab. 6), according to Palumbo (1997) Italian populations are still very large. In the past, Sicilian most declining colonies were located in cerealicolous areas, where placed their nests on rural buildings, while more stable populations lived on rocky habitats (Lo Valvo et al. 1993); in the last decade its decline stopped and it recovered, both in rocky and rural habitats, where colonies of 5-20 pairs breed on roofs of abandoned buildings, particularly in the Gela plain, next to sowable grounds, extensive agroecosystems and grazing, where Mascara \& Sarà (2007) estimate about 300 pairs. In another area in the provinces of Trapani and Palermo, where on late summer huge numbers of this small falcon have been detected, the percentage application of RDP on AUS ranged between $6.22 \%$ and $14.21 \%$.

Coturnix coturnix. It was very fluctuating in '70-'90s, both in Italy and in Sicily and it seems impossible to define a precise trend, but in the last ten years its breeding populations seem stable or increasing, probably thank to agri-environment regulations. During the breeding season, it occurs on areas sown with wheat, secondarily on areas with wheat mixed with forage and on uncultivated land mixed with maquis (Lo Valvo et al. 1993). This makes the species particularly vulnerable for the impact of modern cultivation techniques (use of pesticides and mechanisation growth). Set-aside may have good effects on it. Hunting and poaching have surely negative effects on migrant populations in autumn and spring.

Columba palumbus. It is one of the most increasing species in the last 15 years all over Italy and Sicily (including some small islands), where it colonised afforestations and many villages and towns.

Merops apiaster. Probably due to the increasing of

Tab. 8 - Some suggested changes for Sicilian agroecosystems management to reduce the impact on fauna (greenhouses and horticulture are excluded).

\begin{tabular}{ll}
\hline Agroecosystems & Proposed changes \\
\hline Cerealicolous & $\begin{array}{l}\text { Catch crops, intercropping; Rationalization of fertilization and tillage; } \\
\text { Mechanical control of weeds (false sowing); Seed tanning with safe products }\end{array}$ \\
$\begin{array}{l}\text { Citrus, Olive plantations, Vine- } \\
\text { yards, etc. }\end{array}$ & $\begin{array}{l}\text { Rationalization of fertilization and mechanization; Autumn-winter grassy; } \\
\text { Green manure; Mechanical control of weeds; Biological and integrated con- } \\
\text { trol }\end{array}$ \\
$\begin{array}{l}\text { Almond, Hazel, Carob groves } \\
\text { (arboreal cultures to be neg- }\end{array}$ & $\begin{array}{l}\text { Rationalization of fertilization; Autumn-winter grassy; Green manure; } \\
\text { lected) }\end{array}$ \\
Table wine & $\begin{array}{l}\text { Rationalization of fertilization; Autumn-winter grassy; Biological and integ- } \\
\text { rated control with ecocompatible products } \\
\text { Pastoral }\end{array}$ \\
\hline
\end{tabular}


part-time apiculture, sicilian populations of this species has grown very much, passing from some pairs in the first years of '90s to current hundreds or thousands (Grenci et al. 1997, Massa \& Rizzo 2002). Indeed, it occurs on open places, rich in spontaneous plants, where pollinators, particularly bees concentrate. It has been observed that between 1960 and 1996 apiculture increased very much; in the 1968-71 period, in Europe 5841000 beehives were estimated, increasing in 1992 to 7550000 , mainly since '80s, in France, Greece, Italy, Spain and Portugal (Massa \& Rizzo 2002). In this context, certainly agri-environment regulations favoured this beautiful species.

Hirundo rustica. Sicilian populations of this species has recently increased, colonizing new, both rural and urban sites.

Emberiza calandra. Sedentary, its status is stable, differently from North European populations (Donald \& Aebischer 1997); additionally, migrant populations visit Sicily in winter. During the breeding season it occurs on open areas, grazing, cerealicolous areas and garrigues, while in winter it prefers ploughed lands and sowable grounds. We assume that agri-environment regulations very probably favoured this species.

\section{Increasing and declining selected species of woodlands}

Dendrocopos major. In the last years, thanks to wide afforestations, some euriecious forest birds have extended their range. According to La Mantia et al. (2002), this woodpecker recently colonized artificial woods, including Eucalyptus woods, poplar afforestations and riparian woods, with an amount of variation of $6.4 \%$, covering $26.3 \%$ of $10 \times 10 \mathrm{~km}$ UTM sicilian squares. Its spreading is still continuing today and covers another $25 \%$ of $10 \times 10$ UTM squares (AA VV 2007).

Fringilla coelebs. Sedentary, but also migrant and wintering, in decline as breeder. It occurs on woodlands and arboreal cultivations, feeding in winter on seeds that collects on ploughed land and pastures; before the sunset, small flocks (5-30 individuals) of this species fly from open places to woods, where they shelter during the night. It has been estimated that many thousands of individuals use dormitories in the main sicilian woods and hundreds of thousands of individuals winter in Sicily (Lo Valvo et al. 1993). Consequently, Sicilian woodlands raise to international importance for the conservation of this species.

Periparus ater. Among tit species, it is the only recently increasing; it has colonized some artificial pinewoods, whose implantation dates back to at least 40 years. Other two passerines species were increasing colonizing the same wood habitat, that is Regulus ignicapilla and Phylloscopus collybita. Other species (Cyanistes caeruleus and Parus major) increased their population in function of silvicoltural treatment (Massa et al. 2004).

\section{Conclusions and perspectives}

The Sicilian region is, amongst other Mediterranean regions, certainly one of those with the highest drought risk in the next future. The precipitations have certainly decreased, especially during the autumn and winter periods, changing from an average of $750 \mathrm{~mm}$ (1921-60) to $650 \mathrm{~mm}$ (1961-90, Sciortino 2003). This has possibly affected the fauna, as some of the data related to birds could demonstrate, but it also mainly confirms the necessity of implementing the woodland surfaces, the expansion of the protected areas and mainly a bigger connection between them.

Protected areas and pCIS/SCZ (respectively 69520.98 and 370342.73 ha) are about $18 \%$ of total surface in Sicily (2582588.48 ha) but Regional Parks and most of the Nature Reserves are concentrated in northern parts of the region, $\mathrm{pCIS} / \mathrm{SCZ}$ are scattered in the rest of the territory. Moreover, many pCIS/SCZ lie within protected areas, so the total surface of these sites actually valuable for the ecological network is much lower (194313.21 ha - Cullotta et al. 2004).

Recently, Grove \& Rackham (2001) listed eight factors responsible of erosion; among them, at least the following six are frequently occurring in Sicily: 1 ) bulldozer use; 2) vine implantation on steep and well ploughed land; 3) removal of stone walls in terraced land; 4) picking stones off lands; 5) burning stubble; 6) overgrazing. When tectonics and lithology are favourable, erosion depends mainly on rainfall, particularly on deluges, which are not rare in south Mediterranean areas. Also, the abandonment of agriculture seems to have produced degradation more than a re-naturalization process. Only where wildfire and pasture are absent, the renaturation stopped the degradation (La Mantia et al. 2007). Human activities, indeed, induced changes as the loss of soil, exposing subsoil or bare rock, and consequent changes in environment or vegetation.

Besides the fact that the landscape is tied to the thousand-year history of the island, which in turn by itself encourages its conservation, there are also reasons correlated to the necessity of hydrogeologic and 
environmental protection.

Tab. 8 reports some changes here suggested, that could contribute to reduce the impact of Sicilian agriculture activities on fauna. It clearly appears that economical reasons make the enforcement of some of them difficult (e.g. cereal rotation with legumes), but a positive effect for the farmer will derive from the application of others. The hedgerow implantation, for example, also planned in the Rural Development Policy measures, is today considered largely effective in the agroecosystem management. Hedgerows play an important role as refuge and breeding site for vertebrate and invertebrate species, including many useful to agriculture (pollinators, predators and parasitoids - Barbera \& La Mantia 1991, Massa \& La Mantia 1997, Lo Verde et al. 2002). However, many of them, mainly those growing along rivers, even though playing the irreplaceable role of soil preservation, are largely decreasing, due to the abandonment process involving Sicilian agriculture (Marchetti et al. 2002). Uncontrolled and illegal burning, often associated with overgrazing exploitation, are indeed bringing about a slow and irreversible destruction of these valuable ecotonal habitats. Harvesting and stubble remotion take away nutrients stored within the plants and leave the soil completely uncovered and unprotected, thus suddenly modifying the microclimate, particularly the daily temperature variation. Repeated stubble burning causes decrease of phosphorous, nitrogen and organic matter in the first soil centimetres. Rotation practices, superficial ploughing $(7-10 \mathrm{~cm}$ deep) and elimination of the stubble burning should result in a speed increase of the soil arthropod diversity and a decrease of damage to edge habitats and their fauna.

Finally, a possible reason generally overlooked, of the decline of some species, is the road network development that today allows to reach places once isolated. After the Unity of Italy, only $2500 \mathrm{~km}$ joined all the Sicilian villages and towns, and even in 1940-50 most rural roads were reachable only by riding a donkey. In the last decades road building increased considerably.

\section{Acknowledgements}

We are grateful to an anonymous referee for his advices and useful suggestions. We also thank M. S. Di Bella, who improved English language.

\section{References}

AA VV (2007). Atlante della biodiversità della Sicilia: Vertebrati terrestri. ARPA, Palermo (in press).
Araùjo A, Bibier O (1997). White Stork Ciconia ciconia. In: (Hagemeijer EJM, Blair Mjeds) "The EBCC atlas of European breeding birds: their distribution and abundance". T \& AD Poyser, London, UK.

Azafzaf H (2002). Statut actuel de la population de la Cigogne blanche Ciconia ciconia en Tunisie. Alauda 70: 387-392.

Baldock D, Beaufoy G, Bennett G, Clark J (1993). Nature conservation and new directions in the EC Common Agricultural Policy. IEEP, London, UK.

Barbera G, La Mantia T (1991). I frangiventi nella frutticoltura integrata. Frutticoltura 7/8: 47-55.

Beaufoy G, Baldock D, Clark J (1994). The nature of farming. Low intensity farming systems in nine European countries. IEEP, WWF and JNCC, UK.

BirdLife International (2004). Birds in Europe. Population estimates, trends and conservation status (Burfield I, van Bommel F eds). BirdLife Int. Ser. No. 12, Cambridge, UK.

Brullo S, Scelsi F, Siracusa G, Spampinato G (1996). Caratteristiche bioclimatiche della Sicilia. Giornale Botanico Italiano 130 (1): 177-185.

Conti F, Abbate G, Alessandrini A, Blasi C, Bonacquisti S, Scassellati E (2005). La flora vascolare italiana: ricchezza e originalità a livello nazionale e regionale. In: (Scoppola A, Blasi C eds) "Stato delle conoscenze sulla flora vascolare d'Italia". Palombi \& Partner s.r.l., Roma, pp. 18-22.

Coppola E (1922). Studio sulle condizioni agricolo-zootecniche della zona dei latifondi siciliani. Castrogiovanni Tipografia Eduardo Scandagliato, pp. 123.

Corti C, Lo Cascio P (1999). I lacertidi italiani. L'Epos, Palermo.

Cullotta S, Garfi G, La Mantia T, Marchetti M (2004). La Rete Ecologica siciliana: valore naturalistico delle aree protette e dei siti Natura 2000 e indicazioni per una gestione sostenibile. Naturalista sicil. 28: 509-531.

Dixon J (1994). The potential role of agricultural policy for achieving nature conservation on farmland. In: (Bignal EM, McCracken DI, Curtis DJ eds) “Nature conservation and pastoralism in Europe". INCC, Peterborough, pp. 110-116.

Doderlein P (1874). Avifauna del Modenese e della Sicilia. Giorn. Sci. nat. econom. 5: 137-195; 6: 187-236; 7: 9-72; 8: 40-124; 9: 28-93; 10: 35-71, 133-148.

Donald PF, Aebischer NJ (1997). The ecology and conservation of Corn Buntings Miliaria calandra. JNCC, Peterborough.

Fierotti G (1988). Carta dei Suoli della Sicilia (scala 1:250.000). Palermo, Regione Siciliana, Ass. Territorio e Ambiente - Università degli Studi di Palermo, Facoltà di Agraria, Istituto di Agronomia Generale.

Fornasari L, Violani C, Zava B (1997). I Chirotteri italiani. L'Epos edizioni, Palermo. 
Giglioli HE (1886). Avifauna italica. Le Monnier, Firenze. Grenci S, Massa A, Nobile V, Rizzo MC (1997). Importanza degli Imenotteri (Insecta Hymenoptera) nella dieta del Gruccione, Merops apiaster L. (Aves Meropidae). Naturalista sicil. 21: 287-307.

Grove AT, Rackham O (2001). The nature of mediterranean Europe. An ecological history. Yale University Press, New Haven, USA.

Heath M, Borggreve C, Peet N (2000). European bird populations: estimates and trends. BirdLife International Conservation Series $n^{\circ} 10$.

Heywood VH (1998). The Mediterranean region. A major centre of plant diversity. In: (Heywood VH, Skoula M eds) "Wild food and non-food plants: information networking". Proceedings of the II MEDUSA Regional Workshop (1-3 may 1997, Port El-Kantaoui, Tunisia). Cahiers CIHEAM, Options Méditerranéennes 38: 5-15.

Iapichino C, Massa B (1989). The Birds of Sicily. British Ornithologists'Union. Check-list $\mathrm{n}^{\circ} 11$, London.

La Mantia T (1985). Averla capirossa (Lanius senator). In: Atlas Faunae Siciliae - Aves (Massa B red). Naturalista sicil. 10 ( $\mathrm{n}^{\circ}$ speciale): $174-175$.

La Mantia T (1997). Il ruolo degli elementi diversificatori negli agroecosistemi mediterranei: valorizzazione e relazioni con le popolazioni di vertebrati. Naturalista sicil. 22 (suppl.): 175-211.

La Mantia T (2002). L'arboricoltura da legno nel paesaggio siciliano. Quaderni IAED 15: 135-153.

La Mantia T, Barbera G (2003). Evoluzione del settore agroforestale e cambiamenti del paesaggio in Sicilia. In: (Lo Piccolo F, Schilleci F eds) "A Sud di Brobdingnag. L'identità dei luoghi: per uno sviluppo locale autosostenibile nella Sicilia occidentale". Franco Angeli, Roma, pp. 118-150.

La Mantia T (2004). Ecologia e agricoltura nel parco della Favorita. In Tenuta Reale "La favorita". Fabio Orlando Editore, 89-122.

La Mantia T, Cannella Z (2007). Alcuni dati storici sulla presenza dei grossi mammiferi in Sicilia. In: Atlante della biodiversità della Sicilia: vertebrati terrestri. ARPA, Palermo (in press).

La Mantia T, Columba P, Scalzo G (2000). Considerazioni sull'applicazione del Regolamento CEE 2080/92 in Sicilia. Atti della Tavola Rotonda "Selvicoltura ed Arboricoltura da legno: quale gestione?", Palermo 25 marzo 1999, Collana Sicilia Foreste 7: 89-106.

La Mantia T, La Mela Veca DS, Gherardi L (1999). Chestnut woods on Madonie mountains (Sicily, Italy): reasons for abandonment and possibilities of recovery. Acta Horticulturae 494: 89-91.

La Mantia T, Oddo G, Rühl J, Furnari G, Scalenghe R (2007). Variazione degli stock di carbonio in seguito ai processi di abbandono dei coltivi: il caso studio dell'isola di Pantelleria (TP). Foresta@ 4 (1): 102-109.

La Mantia T, Pasta S (2001). La rinaturalizzazione dei rimboschimenti: proposte metodologiche e ipotesi di intervento nella Riserva Naturale "Grotta di Santa Ninfa". Naturalista sicil. 25 (Suppl.): 299-323.

La Mantia T, Pasta S (2005). The Sicilian phanerophytes: still a noteworthy patrimony, soon a lost resource? In: (Marchetti M ed) "Monitoring and indicators of forest biodiversity in Europe - from ideas to operationality". IUFRO Conference, 15 November 2003, Firenze. EFI Proceedings 51: 515-526.

La Mantia T, Pasta S (2007). Distribuzione pregressa ed estinzione della Foca monaca (Monachus monachus) in Sicilia (Carnivora Phocidae). In: “Atlante della biodiversità della Sicilia: Vertebrati terrestri". ARPA, Palermo (in press).

La Mantia T, Pasta S, Giardina G, Marchetti M (2004). The effect of grazing in Forests: the case study of Ficuzza (W Sicily). International Congress: "Silvopastoralism and sustainable management". Lugo (Spain), 18-24 Aprile 2004. Abstract book, pp. 195.

La Mantia T, Spoto M, Massa B (2002). The colonisation of the Great Spotted Woodpecker (Picoides major L.) in Eucalypt woods and Poplar cultivations in Sicily. Ecologia Mediterranea 28: 65-73.

Lefranc N (1993). Les Pies-Grièches d'Europe, d'Afrique du Nord et du Moyen-Orient. Delachaux et Niestlé, Lausanne, Switzerland.

Lilford L (1862). On the extinction in Europe of the Common Francolin (Francolinus vulgaris Steph.). Ibis Ser. 1 (4): 352-356.

LIPU-WWF (1998). Lista rossa degli uccelli nidificanti in Italia (1988-1997) In: (Brichetti P, Gariboldi A eds) "Manuale Pratico di Ornitologia". Edagricole, Bologna, vol. 2, pp. 67-121.

Lo Valvo F (1998). Status e conservazione dell'erpetofauna siciliana. Naturalista sicil. 22: 53-71.

Lo Valvo M, Massa B, Sarà M (1993). Uccelli e paesaggio in Sicilia alle soglie del terzo millennio. Naturalista sicil. 17 (suppl.): 1-373.

Lo Valvo M, Barera A, Seminara S (1997). Biometria e status della Lepre appenninica (Lepus corsicanus, de Winton 1898) in Sicilia. Naturalista sicil. 21: 67-74.

Lo Verde G, Perricone G, La Mantia T (2002). L'azione di differenti tipi di frangiventi sull'artropodofauna e sulle caratteristiche bioagronomiche di un aranceto nel territorio di Menfi (AG). Italia Forestale e Montana 4: 390408.

Mack Smith D (1968). A history of Sicily. Medieval Sicily: 800-1713. Modern Sicily: after 1713. Chatto and Windus, London.

Marchetti M, La Mantia T, Messana G, Barbera G (2002). Il 
significato dei popolamenti arborei ed arbustivi fuori foresta nel paesaggio agrario e la loro dinamica evolutiva in due aree campione della Sicilia. Italia Forestale e Montana 4: 369-389.

Marsili L, Massi A (1991). Contaminazione da organoclorurati in due Capovaccai trovati morti in Sicilia. Riv. ital. Orn. 61: 77-79.

Mascara R, Sarà M (2007). Censimento di specie d'uccelli steppico-cerealicole d'interesse comunitario nella piana di Gela (Sicilia sud-orientale) (Aves). Naturalista sicil. 31: 2739.

Massa B (1972). La Foca monaca (Monachus monachus Herm.) esiste ancora in Sicilia. Atti Soc. ital. Sc. nat. Mus. civ. St. nat. Milano 113: 385-390.

Massa B (1973). L'Avifauna estiva degli arcipelaghi delle Egadi e dello Stagnone (Trapani, Sicilia). Atti Accad. Gioenia Sc. nat. Catania 5: 63-95.

Massa B (1980). Ricerche sui rapaci in un'area-campione della Sicilia. Naturalista sicil. 4: 59-72.

Massa B, La Mantia T (1997). Benefits of hedgerows-windbreaks for birds and their valorisation in sustainable agriculture. Agricoltura Mediterranea 127: 332-341.

Massa B, Lo Valvo F, Margagliotta B, Lo Valvo M (2004). Adaptive plasticity of blue tits (Parus caeruleus) and great tits (Parus major) breeding in natural and semi-natural insular habitats. Ital. J. Zool. 71: 209-217.

Massa B, Lo Verde G (2007). L'Arvicola del Savi, Microtus savii (De Sélys Longchamps), in agrumeti e vigneti siciliani. Informatore fitopatologico 57 (9): 23-26.

Massa B, Rizzo MC (2002). Nesting and feeding habits of the European Bee-eater (Merops apiaster L.) in a colony next to a beekeeping site. Avocetta 26: 25-31.

Massa B (1985). Atlas Faunae Siciliae. Aves. Naturalista sicil. 9: 1-274 (special issue).

Massi A, Marsili L, Focardi S, Leonzio C, Cortone P (1990). Contaminazione da metalli in tracce ed idrocarburi clorurati in tessuti di Capovaccaio, Neophron percnopterus. Riv. Ital. Orn. 60 (1-2): 29-36.

Médail F, Quézel P (1997). Hot-Spots analysis for conservation of plant biodiversity in the Mediterranean basin. Annals of the Missouri Botanical Garden 84: 112-127.

Minà-Palumbo F (1853). Catalogo degli Uccelli delle Madonie. I. Atti Accad. Sc. Lett. Arti Palermo, 2: 1-32; II. Atti Accad. Sc. Lett. Arti Palermo 3: 1-45.

Morici F (1940). Aspetti e risulati tecnici-economici di imprese pastorali siciliane. Istituto Nazionale di Economia Agraria, Osservatorio di Economia Agraria per la Sicilia, Studi e Monografie, Serie prima 2: 84.

Myers N, Mittermeier RA, Mittermeier CG, da Fonseca GAA, Kent J (2000). Biodiversity hot-spots for conservation priorities. Nature 403: 853-858.

Orlando C (1956). I Picini (sottofamiglia Picinae) in Sicilia.
Riv. ital. Orn. 26: 78-81.

Orlando C (1958a). La Quaglia tridattila Turnix sylvatica (Desf.). Venatoria sicula 12: 342-344.

Orlando C (1958b). Il Basettino Panurus biarmicus (L.). Venatoria sicula 12: 298.

Palumbo G (1997). Il Grillaio. Altrimedia, Matera, pp. 142. Pasta S, La Mantia T (2001a). Note sul paesaggio vegetale delle isole minori circumsiciliane. I. Consorzi forestali e preforestali dell'Isola di Lampedusa (AG) ed effetto degli impianti artificiali sulla vegetazione naturale. Naturalista sicil. 25 (Suppl.): 71-89.

Pasta S, La Mantia T (2001b). L'impatto dell'attività agricola e la gestione delle aree protette: il caso della Riserva Naturale "Maccalube di Aragona". Naturalista sicil. 25 (Suppl.): 197-215.

Priolo A (1954). Quadro sinottico delle osservazioni ornitologiche svolte in Sicilia dal 1940 al 1953. Avocetta 1: 1-13.

Priolo A (1967). Distrutti i Grifoni delle Caronie? Riv. ital. Orn. 37: 7-11.

Rainio K, Laaksonen T, Ahola M, Vähätalo AV, Lehikoinen $E$ (2006). Climatic responses in spring migration of boreal and arctic birds in relation to wintering area and taxonomy. J. Avian Biol. 37: 507-515.

Root TL, Price JT, Hall KR, Schneider SH, Rosenzweig C, Pounds JA (2003). Fingerprints of global warming on wild animals and plants. Nature 421: 57-60.

Ryszkowski L, Karg J, Margarit G, Paoletti MG, Zlotin R (1993) Above-ground insect biomass in agricultural landscapes of Europe. In: (Bunce RGH, Ryszkowski L, Paoletti MG eds) "Landscape Ecology and Agroecosystems". Lewis Publ., Boca Raton, pp. 71-82.

Sarà M (1998). I Mammiferi delle isole del Mediterraneo. L'Epos edizioni, Palermo.

Sarà M (1999). Il "Catalogo dei Mammiferi della Sicilia" rivisitato. Soc. messinese di Storia Patria, Messina.

Sarà M, Siracusa M, Ciaccio A (1987). Estinzione del Gufo reale, Bubo bubo, in Sicilia. Riv. Ital. Orn. 57: 50-56.

Sciortino M (2003). La sensibilità alla desertificazione della Regione Sicilia. In: "La risposta al cambiamento climatico in Italia". ENEA, pp. 31-39.

Stervander $M$, Lindström $\AA$, Jonzén N, Andersson A (2005). Timing of spring migration in birds: long-term trends, North Atlantic Oscillation and the significance of different migration routes. J. Avian Biol. 36: 210-221.

Stresemann E (1943). Die Brutvogel des Sees von Lentini, Sizilien. Orn. Monabster 51: 116-122.

Thomas CD, Cameron A, Green RE, Bakkenes M, Beaumont LJ, Collingham YC, Erasmus BFN, Ferreira de Siqueira M, Grainger A, Hannah L, Hughes L, Huntley B, van Jaarsveld AS, Midgley GF, Miles L, Ortega-Huerta MA, Peterson AT, Phillips OL, Williams SE (2004). Extinction risk from climate change. Nature 427: 145-148. 
Trischitta A (1919). Sull'esistenza del picchio nero Turrisi GF, Vaccaro A (2001). Distribuzione altitudinale di (Dryocopus martius (L.)) in Sicilia. Boll. Ist. Zool. R. Univ. Anfibi e Rettili sul Monte Etna (Sicilia orientale). Pianura Palermo 1: 77-80.

13: 335-338.

Trocchi V, Riga F (2001). Piano d'azione nazionale per la

Violani CG, Massa B (1993). Extinction of the Andalusian lepre italica (Lepus corsicanus). Quaderni di conservazione della natura 9, pp. 102.

Hemipode Turnix s. sylvatica (Desf.) in the Mediterranean region. Bull. Br. Orn. Cl. 113: 225-229.

Tucker GM, Heath MF (1994). Birds in Europe: their conservation status. BirdLife Int., Cambridge, UK.

Zuccarello Patti M (1845). Osservazioni e descrizioni ornitologiche. Atti Accad. Gioenia Sc. nat. Catania 2: 321-335. 